\title{
Collective bargaining systems and macroeconomic and microeconomic flexibility: the quest for appropriate institutional forms in advanced economies
}

\author{
John T. Addison ${ }^{1,2}$
}

\section{Correspondence:}

ecceaddi@moore.sc.edu

${ }^{1}$ Moore School of Business University of South Carolina, 1014 Greene Street, Columbia, SC 29208, USA

2Durham University Business School, Mill Hill Lane, Durham DH1 3LB, England, UK

\begin{abstract}
This paper addresses the design of the machinery of collective bargaining from the perspective of microeconomic and macroeconomic flexibility. In the former context, somewhat greater attention is given over to enterprise flexibility than external adjustment. In the latter context, close attention is also paid to changes in collective bargaining along the dimensions of bargaining coverage, structure, and coordination. Support is adduced for the German, contemporary Scandinavian, and British models. The role of trust in securing micro and macro flexibility also receives attention, suggesting that the polder or Dutch model might also be expected to populate the firmament of fit-for-purpose collective bargaining arrangements.
\end{abstract}

JEL Classification: Microeconomics/Institutions (D02), Institutions and the Macroeconomy (E02), Employment/Unemployment/Wages (E24), Income Distribution (E25), Macroeconomic Policy Objectives (E61), Labor Economics Policies (JO8) Trades Unions (J51), Collective Bargaining (J52), Labor-Management Relations (J53), Public Policy (J58), Comparative Analysis of Economic Systems (P51)

Keywords: Bargaining coverage/structure/coordination, Collective bargaining, Decentralization, Growth, Inequality, Micro/macro flexibility, Pacts, Social pacts, Stabilization, Trust, Unemployment, Voice

The remarkable transformation of the German economy from the 'sick man of Europe' to a lean and highly competitive economy within little more than a decade is rooted in the inherent flexibility of the German system of industrial relations. This system allowed German industry to react appropriately and flexibly over time to the demands of German unification, and the global challenges of a new world economy. (Dustmann et al. 2014, p. 183)

The only realistic aim is to influence labor market outcomes, not to rationalize labor market processes which will continue to display enormous diversity, fragmentation and incoherence. (Teague and Grahl 1998, p. 18) 


\section{Introduction}

This paper charts changing views on a labor market institution from the perspective of microeconomic and macroeconomic flexibility. The particular labor market institution examined here is collective bargaining-other labor market institutions will be mentioned only in passing. And in discussing microeconomic flexibility and reallocation needs, we will be rather more concerned with enterprise flexibility than with considerations of external adjustment. Our discussion of macroeconomic flexibility centers familiarly on the ability of the economy to maintain a low average unemployment rate and to limit fluctuations in the unemployment rate in response to shocks under different collective bargaining regimes.

In discussing micro flexibility, evidence that unionism is associated with wage rigidity constraining labor market reallocation has to be considered in the context of bargaining level as well as alongside the apparent stimulus given to adjustments along other margins. Further, the importance of internal labor markets under both union and nonunion regimes redirects our attention to enterprise flexibility. Theoretical developments in the areas of collective voice and contract theory that focus on internal labor market structuring have offered support for pro-productive union effects. If the promise of unions in this regard remains unfulfilled for the USA, this evidence cannot be uncritically applied to other nations. In particular, some of the more promising performance results are reported for the German dual system of sectoral bargaining in combination with workplace codetermination.

Work on macro flexibility was if anything to portray unionism and collective bargaining in a more positive light once research moved beyond a focus on union density/ coverage and the simple exertion of market power. But the performance of models based on corporatism, modified notions of centralization (most notably the humpshape thesis), and even coordination faded through time. That is, institutions did not affect macro outcomes consistently. Moreover, important changes in collective bargaining beginning in the 1990s in the form of decentralization were not reflected in the stylized institutions.

However, Visser's $(2013,2016)$ updated discussion of national collective bargaining institutions provides a comprehensive breakdown of changes in collective bargaining along the dimensions of bargaining coverage, bargaining structure, and bargaining coordination. His discussion is summarized in the present treatment, and certain key themes uncovered there enlarged upon. These include extension agreements, orientation, and above all decentralization. Visser's taxonomy pays especial attention to decentralization while addressing diversity of practice within bargaining categories. In conjunction with other pieces of evidence, it helps us establish the protean shape of emerging (i.e., decentralized) collective bargaining systems that may be fit-for-purpose in the sense of meeting the requirements of micro and macro flexibility. Supportive case study material drawn from studies of innovative practices associated with decentralization is provided.

Specific support for the German model and the modified Scandinavian model is qualified by very recent theoretical work pointing to the superiority of fully decentralized collective bargaining systems also reviewed here. It is argued that these models of firm-level bargaining are not inconsistent with the German and Scandinavian sectoral models. By the same token, one has to recognize that these theoretical developments more directly make a case for the Anglo-Saxon model, albeit one probably differentiated from the two 
other models by its greater reliance on managerial control. This is a not unimportant conclusion and is consistent with Freeman's (1998: 15) evocative "more than one road to Rome" remark.

It has long been argued that trust may be just as important in securing macro (and micro) flexibility as the structure of collective bargaining itself. In tackling the neglected issue of trust, its association with unemployment is examined together with some supplementary research findings on the relation between trust and the design and the quantity of labor market legislation. In addition, the intriguing notion that the very scale of the changes in wage-setting institutions in recent years may have served to erode trust is addressed. Social pacts are also considered since they may be viewed either as requiring trust or as substituting for it. In discussing the polder model 19822000, it becomes clear that there are also features of the collective bargaining system that potentially help build trust. For this reason, our series of fit-for-purpose collective bargaining models may be expanded to include the contemporary Dutch system.

The last major theme examined in this report is the vexed question of earnings dispersion, analysis of which has gained more currency of late because of the association between inequality and growth. Information on this association is reviewed before turning to union decline and inequality. Two basic views of unions and inequality are offered. The first is the standard one: unions are associated with reduced inequality, the corollary being that their decline has exacerbated it. The second is associated with the recherché notion that unions have in fact become less interested in redistribution. Even if one accepts that union decline is an important determinant of rising inequality, however, there is no general presumption in favor of strengthening the institution. The growth card is complicated precisely because losses of competitiveness may have caused union decline.

However, to take up a separate issue, and one remitted to our concluding section, might not the case for offering support to unionism be stiffened by the likelihood of a shortfall in worker voice in the wake of union decline? At face value, this case is rather more convincing, and mandates favoring (some form of) worker representation may be indicated. That said, the evidence, while not unequivocal, points to a dramatic expansion of British non-union voice in the wake of union decline in that nation as well as the active suggestion that management has had an incentive to invest in non-union voice.

It is important to recognize that the present treatment is a partial one. It reflects the very real state of flux in the institutions of collective bargaining that awaits formal incorporation into models of the covariation of labor market institutions and macro outcomes. Further, at the more detailed micro level, it reflects in part the tendency of research to focus on Anglo-Saxon nations and a few key continental European nations and also in part the research preoccupations of the author. As a result, some nations will be mentioned only in passing and others largely ignored. The limitations of this explorative analysis have therefore to be stated at the outset and borne in mind throughout. The goal is to establish key associations and the most important trends in a framework that seeks to identify a plurality of fit-for-purpose regimes rather than favoring any single model.

\section{Microeconomic issues}

In this first substantive section of the paper, we consider the issue of micro flexibility and collective bargaining. Based on recent studies of firm survey data, our discussion 
begins with the process of adjustment at the firm level in respect of price, wage, and employment responses to shocks, wage rigidities and non-wage labor cost flexibility, and the frequency and manner of wage and price changes, as well as the way in which the wages of newly hired workers are linked to market conditions and to the wages of existing employees. The associations uncovered here also have a direct bearing on macro adjustment. And while the backdrop is the constraints imposed by collective bargaining on firm-level reactions, flexibility and diversity are also in evidence. The question of enterprise flexibility is taken up in the second part of the section, where we discuss union impact on enterprise performance more generally. This broader focus allows us to introduce some key themes taken up in this review on the suitability of different collective bargaining regimes. That is, our examination of individual countrylevel studies goes part of the way to establishing the components of workable models of collective bargaining while raising the issue of trust.

\subsection{Some recent micro evidence on price and wage flexibility and collective bargaining}

A recent group of articles have exploited data from the Wage Dynamics Network (WDN), a novel firm-level survey sponsored by a consortium of central banks in the EU and coordinated by the European Central Bank, containing qualitative information on various firm adjustment mechanisms, to address micro adjustment processes and the role of rigidities. The survey was conducted in 2007/2008 in 17 EU countries and covered some 17,000 firms. As we shall see in Section 3, it has also been used by Boeri $(2014,2015)$ in support of his criticism of two-tier bargaining regimes-arrangements in which plant-level wage negotiations supplement industry-level bargaining-as failing to improve either microeconomic or macroeconomic adjustment to shocks.

An important study by Bertola et al. (2012) focuses on firms' reactions to hypothetical cost-push shocks: either an unanticipated increase in the cost of an intermediate input or an unanticipated permanent increase in wages. The four possible responses were (a) an increase in prices, (b) a reduction in profit margins, (c) a reduction in output, and (d) a reduction in costs. The "relevance" or importance of each reaction was also taken into account. The authors' probit regressions indicate that firms facing product market competition, or exporting much of their output, are less likely to increase prices and more likely to reduce costs after a wage shock assumed common to all firms in the industry. Further, the presence of collective agreements at the industry or national level (but not at the firm level) makes a price increase more likely. On the separate question of reducing costs after a cost or wage shock (having identified six such strategies: reduce the number of temporary/other employees, reduce the number of permanent employees, reduce the hours worked per employee, reduce the flexible wage components, reduce the base wages, and reduce the nonlabor costs), Bertola et al. report that firms operating in a highly competitive product market environment were less likely to reduce non-labor costs and more likely to reduce labor costs. This wage reduction route was less likely in situations in which firms are subject to labor contracts signed at levels higher than the firm. Cost reductions in these circumstances were secured by cutting employment and in particular temporary employment. Finally, it is speculated that completion of the single market and monetary union by stimulating product market competition and promoting deregulation may have helped foster macroeconomic stability, creating a favorable milieu for a rule-based, credible policy regime. 
A second study by Druant et al. (2012) examines the frequency and character of wage and price increases and their interrelation. (Recall that the degree of wage and price rigidity determines the speed of adjustment of the economy to macroeconomic shocks and with it the scale of the adjustment costs.) The authors' examination of the speed with which firms change prices and wages indicates that the frequency of the latter is roughly one half that of the former-although both "series" display considerable time dependence. The overall stickiness of wages thus exceeds that of prices. The frequency of wage adjustment evinces lower dispersion across sectors, and higher dispersion across countries, than does the frequency of price adjustment. Coupled with widespread wage indexation, the implication of price and wage rigidity is real wage rigidity, which makes the adjustment of the economy to aggregate shocks more costly. The authors' cet. par. analysis of price and wage rigidity at the firm level indicates that prices are more flexible where competitive pressures in product markets are strong and where labor costs account for a smaller fraction of total costs. Wages are more flexible where bargaining is decentralized (being conducted at the firm level as opposed to the national/sectoral/regional level) and where the coverage of collective bargaining and the stringency of employment protection legislation are low. Finally, descriptive evidence is provided (e.g., on the comparable frequency of wage and price changes and the synchronization between the timing of wage and price changes) showing that wages and prices feed into each other at the firm level and that wage and price rigidity are interrelated especially in labor-intensive sectors.

Babecḱy et al. (2012) investigate nominal wage rigidity and labor cost adjustment practices, exploiting questions in the Wage Dynamics Network (WDN) inquiring about instances of freezes in the base wage and the use of ( $\mathrm{six}$ ) other policies to cut labor costs. They find that firms subject to wage rigidity have an increased likelihood of using other margins across the board. Changes in bonuses and non-wage benefits are two such margins of adjustment. Focusing on the results for unionization, where the key variables are the percentage of workers covered by collective agreements and the structure of bargaining (individual negotiations with workers, firm-level agreements with unions, sectoral/national agreements, and both firm-level and national/sectoral bargaining), the main findings are twofold. First, union presence is associated with more intensive use of most margins, even after the effect of nominal wage rigidity is taken into account (which therefore appears to be capturing constraints not explained by unionism), so that although unions may constrain wage flexibility in ways not uncovered by the survey, they may well facilitate the use of alternative labor costcutting strategies. Second, firm-level collective bargaining is associated with greater use of external adjustment as a means of lowering labor costs (viz. hiring new employees at lower wages and encouraging early retirement). The authors speculate that this might indicate that local agreements place greater emphasis on insiders' interests.

The final study in the series examines differences in wage setting between newly hired and incumbent workers. Galuscak et al. (2012) report findings as to the relative importance of internal versus external factors in the setting of wages for newly hired workers. In general, the former are found to be more important influences than the latter. The internal factors are the importance of the wages of similar employees in the firm and the ruling collective agreement (irrespective of its "level"), and external factors comprise the importance of the availability of workers with similar characteristics 
outside the firm and the wages of workers with similar characteristics outside the firm. (The relevance of the question is that it has a bearing on the debate over the cyclicality of the wages of new hires and in particular whether these are more flexible/respond more strongly to changes in unemployment and productivity than do the wages of incumbent workers.) Galuscak et al. also report that internal pay structures are even more binding when there is labor market slack. The bias in favor of internal factors has a basis in consideration of fairness and the need to prevent a negative impact on effort. This general result is mediated by cross-country and within-country differences. The authors' pooled cross-country probit estimates of the probability that external factors dominate in determining pay point to positive associations in the cases of employee turnover, employee skill level, and the degree of product market competition. On the other hand, firms with high collective agreement coverage have a substantially lower probability of reporting external factors as the main determinant of hiring pay. ${ }^{1}$

Although this evidence on adjustment processes points to greater wage inflexibility under collective bargaining, and higher-level bargaining in particular, the studies also suggest that unionism may nonetheless facilitate flexibility along other margins of adjustment. (Positive aspects of avoiding repeated recontracting will be noted below.) Lacunae of the WDN include its cross-sectional nature, basis in subjective responses, and effective omission of Germany, inter al., from the sample.

\subsection{Micro flexibility more broadly}

It is conventional to discuss micro flexibility in terms of labor allocation, to include movements of workers between jobs, industrial sectors, and geographic regions. Much attention has been given over to the impact of institutions other than unions and in particular unemployment insurance and employment protection legislation because of their pivotal role in reallocation and unemployment (see, respectively, OECD 2006; OECD 2010; Bassanini 2011). While noting that there has been altogether less research on the effects of labor market regimes on reallocation, unemployment incidence, and unemployment duration, Blanchard et al. (2013) identify three such regimes according to the combination of measures deployed. At the price of some imprecision, as these authors indeed note, the regimes are (a) the low employment protection/low unemployment insurance mix offered by the Anglo-Saxon model, (b) the medium-to-high employment protection/generous albeit qualified unemployment insurance/active labor market policy combination of the Nordic model, and (c) the high employment protection/generous unemployment insurance/but limited active labor market policies of the Continental model. Regime (a) is characterized by large labor flows, short jobless duration, and low unemployment and regime (b) by significant reallocation but low unemployment. Blanchard et al. accept that this depiction of labor market regimes is something of a caricature and is incomplete in not addressing the (critical) contribution of collective bargaining structures to flexibility. Partly for this reason, they eschew identifying countries making up model (c), which is labeled a failure in view of its limited reallocation and higher unemployment, although they do exonerate Germany by virtue of the Hartz legislative reforms. The goal of the exercise is to identify regimes that promote micro flexibility, the influence of collective bargaining structures being seen as having more to do with macro flexibility. 
Blanchard et al. observe that flexibility achieved through (the Nordic model of) flexicurity-namely a system that seeks to reconcile the managerial prerogative to hire and fire with the workers' need for security or, more bluntly, the protection of workers not jobs-may be especially attractive in view of its comparative distributional implications. However, even if widely regarded as the direction to go to reform labor market institutions, it is cautioned that the features of the Nordic model may not replicable in practice. Specifically, it is argued that the success of flexicurity may in turn reflect the degree of trust between firms and workers and between citizens and their governments.

The above typology differs from the more detailed classification adopted in the present treatment. But this prior, a more broadly based distinction between labor market regimes is pertinent for a number of reasons. In the first place, it recognizes different concepts of flexibility. Next, it directs our attention to the interplay between institutions. Finally, it elevates the importance of trust between workers and firms and their workers and citizens and their government. Trust is a variable that affects both micro and macro analysis of institutional design and performance, and it will figure prominently in our developing discussion.

In Section 3, we will return to examine macro flexibility as reflected in the ability of the economy to maintain low employment (inter al.) in the face of macroeconomic shocks. For the present, however, we continue with micro flexibility issues and will accord within enterprise flexibility and adjustment more emphasis. To set the scene, let us begin with the conventional monopoly theory of unions. This sees their effects as unequivocally negative. Viewed as combinations in restraint of trade, unions introduce distortions into what would otherwise be efficient labor markets. They distort labor market outcomes due to the increase in compensation above competitive levels and impose deadweight losses (i.e., with greater than optimal employment/output in the non-union sector and too little employment/output in the union sector). This misallocation of resources is not nullified by any subsequent hiring of higher-quality labor by unionized employers, even if that is in fact what occurs (see Hirsch 2004b: 422). To these losses in welfare, it is conventional to add the output costs stemming from the union rulebook and reduced management discretion. That said, it is less common today to further add in putative output losses from strikes, either on the grounds that these can in practice be averted by (intertemporal or interfirm) substitution or because of the now widespread acceptance of the notion that strikes are in a sense accidents, strikethreat power being manifested in the wage premium rather than stoppages.

But there is a countervailing view of unions that emphasizes their value-enhancing effects. The chief exponents of this collective voice model of unionism are Freeman and Medoff (1984), whose focus is upon the operation of internal labor markets. Freeman and Medoff note the ambiguity introduced by long-term attachments between the firm and much of its labor force for the efficiency properties of the standard quit or exit mechanism. The firm's reliance on quits to extract information relevant to the design of an efficient mix of wages and working conditions may introduce inefficiencies by focusing on the preferences of the marginal worker rather than those of older, more stable, and potentially more valuable employees. (There are also mobility costs on the other side of the market.) As a result, voice or direct communication between the worker and the firm fulfills the role of bringing actual and desired conditions closer together. 
Crucial to this argument is that many working conditions are public goods in the sense that their consumption is non-rival, such that exclusion from their consumption is either difficult or impossible (examples include safety conditions and line speeds). Without some form of collective agency-which the authors at all times equate with autonomous unions-the worker's incentive to express his or her preferences would be too small. Another public goods aspect of the workplace arises from complementarities in production. In such circumstances, the attitudes and morale of the worker become potentially important inputs into the production process. On the same reasoning as employed earlier, collective organization may increase output through a joint determination of effort inputs, perhaps more so through increased cooperation between workers in continuity markets. We note parenthetically that for the public goods argument to have force, and as Freeman (1976) notes, two further conditions have to be met. First, there must be costs to using the regular market because if quitting were costless, the individual worker could simply choose the employer whose working conditions most closely approximated his or her preferences. Second, the workplace has to be buffeted by unforeseen shocks that change its nature in an informational context; otherwise, there would be no need for the union's demand-revealing function after the formative match. Note, also, that a distortion of the separation decision-a firing tax-is also central to the choice by workers and firms for collective over individualized wage setting in Boeri and Burda's (2009) model of endogenous collective bargaining.

Thus, there are a number of largely informational channels through which unionism as the instrument of collective voice can improve the operation of the workplace. ${ }^{2}$ Their most tangible manifestation is the reduction in quits-holding wages constan$\mathrm{t}$-attendant upon the substitution of voice for exit. Hiring and training costs are thereby reduced, and investments in specific capital increase in relation to general investments, facilitated by seniority systems.

But there is also the important issue of governance. Here, the analysis of Freeman and Medoff is consistent with modern contract theory, wherein governance refers to the policing and/or monitoring of incomplete employment contracts. Unions might facilitate long-term efficient contracting in a number of ways. A union specializing in information about the contract, and in the representation of workers, can help make credible (truthful) employer claims about the onset of adverse states of nature that might otherwise be discounted by the workforce to the detriment of the joint surplus of the enterprise. Again, workers may withhold effort and cooperation when the employer cannot credibly commit to take their interests into account. In certain circumstances, the union may even be construed as an agent of the employer in policing worker effort or indeed of the shareholder principal in reducing agency problems stemming from the divorce of ownership and control in the modern corporation.

Recognition of transaction costs opens up a number of possibilities for positive union effects at the firm level, including those stemming from potential "hold-up" on the part of the employer. We note that some such contract theoretic issues are addressed in the institutionalized corporatist model of Teulings and Hartog (1998), who argue that corporatism achieves allocative efficiency through the establishment of ex ante nominal binding contracts that obviate the need for inefficient ex post negotiation or recontracting (see the macro flexibility discussion below). Nevertheless, there are many uncertainties and lingering ambiguities in all of this. A key problem arises from the threat of 
union punishment deemed necessary to make credible an employer's ex ante promises and the wider implications of the exertion of this bargaining power. What, then, of bargaining power in the Freeman-Medoff model? As a practical matter, unions are seen as having two faces-a monopoly face and a collective voice face-so that the net effect is always an empirical question. Indeed, collective voice in this particular model has very little traction unless it leads to a positive managerial response.

What, then, does the evidence on unions and firm performance/enterprise flexibility suggest? Were we to focus on the US evidence alone, the modern view of unionism would not fare too well. First, as far as the keynote productivity variable is concerned, union effects are small and to all intents and purposes close to zero on average (see Addison and Hirsch 1989; Hirsch 2004b). Second, productivity growth appears lower in union regimes, although this particular result seems to be the consequence of union firms being located in slower-growing sectors (Hirsch 1991). Third, if neither result points to negative direct effects of unions, findings with respect to profitability are of greater concern. In one sense, a negative profitability effect is to be expected given the size of the union premium (see below) in conjunction with a close-to-zero productivity effect. Virtually all US studies point to lower profitability in union regimes irrespective of the profit measure used (see Doucouliagos and Laroche 2009). At issue, however, is the source of the union gain. For Freeman and Medoff, the process is merely a redistributive effect with no implications for efficiency. But, as Hirsh (2004b: 433-434) documents, there is little to suggest that concentration-related profits are an important source of the gain. More potent sources are earnings associated with limited foreign competition and growing firm/industry demand, inter al.

Fourth, yet more concern stems from union effects on investments in tangible (i.e., investment) and intangible (R\&D) capital. Influential research by Hirsch (1991) confirms that unions capture some share of the quasi rents that make up the normal returns to investment in long-lived capital and R\&D. (This, then, is one component of the union profit effect, discussed earlier). Firms seek to limit their exposure, most obviously by cutting back on these investments. There are both direct and indirect union effects: the former are caused by the wage tax while the latter stem from the reduction in profits (relevant because of imperfect capital markets).

Fifth, and as anticipated, lower profits and investment are reflected in lower employment growth (e.g., Leonard 1992) if not seemingly in higher failure rates (e.g., DiNardo and Lee 2004). ${ }^{3}$ That being said, firm birth rates may be lower in more highly unionized industries (Dunne and Macpherson 1994) while, in extremis, and by way of explanation, substantial wage premia may be viewed as offering a source of wage flexibility via contract concessions (Hirsch 2004b: 438).

Apart from a union "voice" effect on quits that clearly dominates any wage effect on quits, these are rather negative results. Not only do they appear to underpin the precipitous decline in US unionism, for example, Hirsch (1991) finds a negative correlation between firm profitability in the late 1970s and subsequent changes in union density between 1977 and 1987, they also threaten the very existence of private-sector unions. Before turning to the other-country experience, however, some more positive aspects should be cited. First of all, one US study examining the effects on labor productivity of various working practices, information technology, and management procedures in conjunction with unionism offers a brighter scenario (Black and Lynch 2001). Using 
cross section and panel data on 638 establishments from a nationally representative sample of manufacturing establishments, 1987-1993, it reports that a hypothetical union plant embracing benchmarking and total quality management, with $50 \%$ of its workers meeting on a regular basis (a measure of employee involvement) and operating profit sharing for its non-managerial employees, would have $13.5 \%$ higher productivity than a non-union plant with none of these practices. By contrast, the corresponding differential for a high-performance non-union plant is put at only $4.5 \%$-although if union and non-union plants possessed none of these workplace practices, the latter would have $10 \%$ higher productivity than the former. As a matter of fact, however, such innovative union plants constituted a tiny share of union workplaces in this study sample.

Second of all, and relatedly, a set of micro studies have pointed to the importance of good industrial relations or trust to measured outcomes, as suggested by the collective voice model and also as reported for the underground bituminous coal industry by Freeman and Medoff (1984). Thus, a number of case studies have suggested that firms or plants characterized by cooperation, employee involvement, and relatively low grievance rates tend to have higher levels of productivity and economic performance (e.g., Katz et al. 1983). More recent studies include Kleiner et al.'s (2002) investigation of the impact of the industrial relations climate on productivity at a major aircraft assembly plant, 1974-1991, and Krueger and Mas' (2004) careful case study of the effect of labor relations on product quality in a tire plant in the mid-1990s.

Nevertheless, to what extent do the preponderantly negative results for the USA carry over to other countries? In the first place, given that the US union wage gap is unusually high compared with that in other countries (see Blanchflower and Bryson 2003; Bryson 2010; Hirsch 2004a), one might expect the main US results reported above to be in the vanguard of adverse effects. This is the broad thrust of the comparative literature, although it is sparse and still confined to a comparatively few developed and largely Anglo-Saxon nations (see, for example, Aidt and Tzannatos 2002; Metcalf 2003; Doucouliagos and Laroche 2003, 2009).

The comparative six-nation study by Metcalf is of especial interest because of the nature of its treatment of the USA, Britain, and Germany, as well as high-performance work practices, and the range of outcomes addressed. While noting the unfavorable productivity results for strongly organized British workplaces in 1980, adverse effects of increased union density in Canada, and strongly negative productivity outcomes for Australia in respect of both union density and coverage, Metcalf offers a more positive diagnosis for the USA and Britain. Thus, he emphasizes the Black and Lynch (2001) study reviewed earlier for the USA and reports roughly comparable results obtained in his own research using data from the Management Questionnaire of the 1998 British Workplace Employment Relations Survey and having a basis in partnership agreements. Metcalf offers some detail on the impact of such partnerships, using subjective outcome indicators for productivity (and financial performance). Partnership is defined as obtaining where the union negotiates pay and management negotiates with or consults the union on recruitment, training, payment systems, handling grievances, staff planning, equal opportunities, health and safety, and performance appraisals. Metcalf's probit regressions indicate that when a workplace with union recognition also has the hallmark human resource management practices, its productivity (and financial 
performance) is much enhanced; that is, the probability of above-average levels of and changes in productivity (and financial performance) are significantly improved. A human resource management (HRM) workplace with no union has a superior productivity and financial performance to a unionized workplace with no HRM, but in this study, only in the case of productivity growth are the best performing workplaces those with both HRM and union recognition.

Further in the case of Britain, he emphasizes that what was true for the nation in 1980 was no longer true thereafter. British (and indeed Australian) productivity shortfalls were largely attributed to multi-unionism (i.e., the presence of more than one union in a workplace). Metcalf's review of the German evidence on productivity, and indeed the other performance outcomes, largely pertains to works councils rather than unionism per se. Although his portrayal is accurate and pays appropriate attention to the dual system of industrial relations in that nation, the evidence in question has been overtaken by events in the form of new research using nationally representative samples of establishments and will be addressed below.

In the case of profitability, the main result is the weaker performance of unionized companies. But two aspects of Metcalf's review stand out. First, he again advances the idea that new forms of organizing work and union management relations hold out the promise of maximizing shareholder wealth and employee welfare, drawing on the one US financial performance study to report positive results (viz. Batt and Welbourne 2002) and in particular its rationale that there has been a sea change in contemporary labor and product markets away from oligopolistic markets, mass production approaches to work organization, and conflictual labor relations. Second, the British evidence reviewed by Metcalf is interesting in suggesting that, by the end of the 1990s, there was no longer a negative association between union presence and financial performance. $^{4}$

Turning to union effects on investment in physical capital, Metcalf notes that the British evidence is mixed with the clearest negative effects being reported for 1980-1984, namely a period largely prior to far reaching industrial relations legislation. ${ }^{5}$ This shift in the impact of British unions in the decade of the 1990s compared to the 1980s has been widely observed in the literature. Thus, for example, Addison and Belfield (2004a) chart the changes in the impact of British unions at a time when union density almost halved-from 53 \% in 1979 to $28 \%$ in 1999. They report clear evidence of a diminution in the effects of unions on wages, financial performance, and productivity through time-even if certain unfavorable effects of unions are found to persist such as slower employment growth and elevated absenteeism.

The question on unions and investment returns us to the German research literature. As Metcalf correctly anticipated in his survey, this literature on unions and firm performance is in a state of flux because of the ongoing decentralization of collective bargaining. But it is also an issue of emphasis. Until very recently, the research literature focused on either unions or works councils-more typically the latter. Yet, as is widely known, German industrial relations conform to a dual system, with collective agreements traditionally being negotiated at the industry level between trade unions and employer associations, while works councils operate at the plant level. Works councils, though formally independent of unions, oversee the implementation and coordination of collective agreements at the workplace level and have important information, 
consultation, and codetermination rights under law. The two institutions need to be considered in tandem.

German works councils are viewed as an exemplary voice institution by (one of) the framers of the collective voice model (see Freeman and Lazear 1995), not only because of their informational and governance functions but also because of the legal limits placed on their authority. That is, they cannot strike and cannot formally engage in bargaining over wages unless expressly authorized to do so under the relevant industry-level bargaining agreement. So one may speak in principle of a decoupling of the factors that determine the size of the joint surplus from those that determine its distribution, the latter being the "responsibility" of the union at the industry level. Despite the provenance of the institution, however, we do not know whether there is a sufficient decoupling in practice given that the authority of the entity implies material bargaining power. Theory, therefore, does not provide an unambiguous answer as to the efficiency consequences of works councils either. (A trust-based theoretical take on the German model is offered in Exhibit 1). A final point is that works council authority in Germany has grown under the decentralization of industry-wide

\section{Exhibit 1 Micro foundations of trust: the German model}

It has recently been argued that the continuing endurance of the German model owes much to trust. In particular, Marsden (2015) contends that this is underscored by the presence in some but by no means all sectors of a high-discretion learning model of work organization, which he contrasts with the more managerial-directed lean model in Britain. He claims that German manufacturers have been successful in repositioning themselves within international supply chains (and the so-called trade in tasks) as reflected in a rising share of exports in manufacturing gross value added. The idea is that holding one's place in international supply chains is very competitive, requiring firms to attain quality standards needed for the final product in the chain while being innovative in managing process and cost improvements. The work practices of German firms, so the argument runs, have kept pace with these changes via learning-based work systems. In Germany, a strong foundation of intermediate skills is said to provide an effective basis for this particular model, the hallmark of which is task flexibility and on-the-job learning or high-performance work systems in short. (The alternative works systems, in addition to the lean model mentioned earlier, are the Taylor approach and the craft/simple model). Marsden develops a model in which stable cooperation with the learning model is enhanced via a strong institutional framework. This is because of the need for "goodwill cooperation" in employment relationships founded on incomplete contract and reliance investments. The German industrial relations system has provided the necessary institutional support, which is why employers in sectors using the learning model have continued to work with the institutions of codetermination that encourage the expression of voice. Both individual voice and collective voice are important, and Marsden argues that these are complements when collective voice exists as of right. Mutual goodwill requires stability, meaning that faster adjustment to economic shocks can potentially strain relationships of mutual trust. Alternatively expressed, the learning model may be difficult to sustain if the institutional support that currently involves a sharing of firms' and workers' economic risks and adjustment costs more widely, with other firms, other workers, and the state is undermined. Marsden also contends that the partitioning of the dual system-where the responsibility for wage bargaining is separated from workplace issues, being assigned to unions and works councils, respectively — has provided support for cooperation while at the same time making it harder to use strength in one area to support demands in another. He cautions that this partitioning is jeopardized by the erosion in the coverage of collective agreements. 
collective bargaining. Under opening clauses and pacts for competitiveness, unions have provided for greater flexibility within industry-wide collective bargaining agreements.

While it is true that the findings of the German literature reported in Metcalf have been superseded by a new literature having a basis in nationally representative data, the issue of works council impact remains mixed (see, in particular, Addison 2009, Chap. 6). But there is some suggestion that their effect on firm performance (productivity) may be positive in circumstances where they are firmly embedded in the dual system and their effect on wages altogether less pronounced (Hübler and Jirjahn 2003). Here, rent seeking might be confined to collective bargaining proper. However, since greater works council involvement is the handmaiden of decentralization, more work is required on the new bargaining arrangements under opening clauses and pacts for competitiveness. We shall provide evidence on both of these contractual innovations in the next section when discussing decentralization of collective bargaining. For present purposes, however, we shall focus on investments in intangible capital, where many of the standard theoretical arguments carry over from investment in physical capital. Again, most of the empirical literature on innovation deals with the US experience, and the evidence is no more favorably disposed toward unionism than in the case of investments in physical capital (Menezes-Filho and van Reenen 2003). Here, however, the German literature subsequent to Metcalf's review has been altogether more positive. Thus, a recent study by Addison et al. (2013), using data from the IAB Establishment Panel for the observation window 2007-2012, provides encouraging estimates of the effect of collective bargaining on four categories (three product and one process) of innovation. Since both collective agreement and workplace codetermination status are observed, the modeling strategy is ultimately designed to generate estimates of the effect of trade unions and works councils on innovation that are free, as far as possible, from the contamination of selection issues associated with endogenous decisions regarding the choice of these two institutional entities. Prior to that, controlling for a wide set of covariates, the authors' estimates using pooled data suggest that the conjunction of the two institutions is relatively friendly to innovation. Arguments associated with more innovation of all types included training at the workplace and competition but not the profit situation. The authors' subsequent analysis of sectoral agreement and works council transitions and their relationship to innovation is conducted within a differencein-differences framework in which establishments leaving/joining a sectoral agreement are compared with those that remain covered/uncovered. It is found that joining a sectoral agreement in the presence of a works council, or leaving a sectoral agreement in its absence, seemingly proves advantageous to innovation. Taken as a whole, the study provides only weak evidence that collective bargaining inhibits innovation but stronger support for the notion that secotral bargaining in conjunction with works councils - the dual system - offers a favorable milieu for innovative activity.

The distinctive features of the German works council may be the key. Here, we note in passing that French research is less favorable to the entity. In particular, a study by Fairris and Askenazy (2010) fails to detect a positive association between works council presence and firm productivity. Indeed, if anything, the association is negative. Further, although there is no indication that the estimated association is influenced by union status on the German pattern, worker voice and high-performance work practices (HPWPs) are present in French firms irrespective of works council status and yield positive and statistically significant effects on firm productivity throughout. That said, international comparisons 
of works councils mainly take the form of qualitative case studies. In a recent departure, however, Van den Berg et al. (2013) offer a cross-country quantitative analysis of the effects of workplace representation on firm performance using the European Company Survey for 2009. The authors effect a comparison across $25 \mathrm{EU}$ nations aggregated in five cultural clusters, namely Germanic, Southern European, Anglo-Saxon, Scandinavian, and Transition. It is reported that the subjectively defined measure of firm performance (the "economic situation" of the firm) is adversely affected by councils in the Germanic cluster (comprising Germany, Austria, the Netherlands) whereas the contrary obtains for the two-nation Anglo-Saxon cluster, comprising Ireland and the UK, in respect of their voluntary information and consultation bodies. Limitations of the study include the focus on economic performance rather than (perceived) labor productivity and work climate, the clustering of nations given both material and subtle differences in institutional regimes (although for an alternative approach that avoids clustering, see Jansen 2014), and the endogeneity of workplace representation. These factors coupled with the cross-sectional nature of the data raise serious questions about the robustness of the empirical evidence and may contribute to the study's frankly surprising results. However, given a move toward decentralized bargaining, the study's use of comparative workplace data is a welcome development and one that may be linked to national collective bargaining systems.

This returns us to some additional observations on the union-high-performance work practice nexus, beginning with the issue of the role of HPWPs in enabling union firms embracing these transforming industrial relations practices to outcompete not only traditional non-union firms but also those non-union firms with the same set of practices. Unfortunately, despite the suggestion in the literature that combinations of innovative practices and worker representation can yield productivity gains, there should be no pretense to precision in all of this in the sense of the literature having uncovered a welldetermined hierarchy for productivity performance-that is, with unionized plants having innovative practices at the apex-still less a blueprint for the future of unions. Vulgo: this conclusion and the use of synthetic workplaces to identify hierarchies is frankly premature. For example, a British study by Wood and de Menezes (1998) that uses latent variable analysis to search for identifiable patterns in the use of 23 high-performance practices, and is able to identify a progression of what it calls high-commitment management (high HCM, medium-low $\mathrm{HCM}$, low-medium $\mathrm{HCM}$, and low $\mathrm{HCM}$ ), reaches rather sobering conclusions. First of all, neither high HCM nor low HCM are distinctive with respect to unionism. Second, in examining seven dimensions of firm performance-productivity, changes in productivity, financial performance, job creation, employee relations climate, labor turnover, and absenteeism, in no case do high HCM plants perform better on any performance criteria than all the others, although they do perform better than some types.

The German evidence concerns the association between works councils and HPWPs and is reviewed in Addison (2009, pp. 84-93). In common with other countries, the research has focused more on the effect of the practices themselves than with their interaction with workplace representation. One key result is that practices that appear to have no positive value (or even negative effects) emerge on closer inspection to be pro-productive, while yet others that are on the face of it productive are found to have no effect on performance having controlled for their endogeneity. There is also some strong suggestion that positive payoffs may only be realized in companies with works councils, although we cannot discount the possibility that the unobserved characteristic of "good management" lies at the heart of the 
matter. To be sure, there are also results, allowing for selection and using panel estimates, pointing to the productivity of some types of training and of more training in works council regimes, whose evidence is consistent with works councils reducing turnover and incentivizing employers to provide greater training. However, given the lingering ambiguity as to the costs of the practices in question, and profound causality issues attendant upon the unobserved timing of these transforming industrial relations practices, the literature cannot yet be said to have uncovered a well-determined hierarchy for firm performance.

Finally, we consider union impact on employment. If there is one constant in the literature, it is that unions appear to retard employment growth. For Anglo-Saxon countries, the magnitude of the effect is approximately $3 \%$ a year (see Addison and Belfield 2004b). Yet, in the light of the foregoing discussion, employment growth is a not unambiguous indicator. For example, unionized plants shedding restrictive/protective practices (Britain, post-Thatcher?) might grow employment less than non-union plants. More positively, the same result might be produced by unionized firms adopting new forms of work organization and union management relations. In other words, while mobility can be expected to ease the problems of structural economic adjustment, an equal if not more important criterion of micro flexibility is enterprise flexibility.

In a recent study of the effect of German collective bargaining on employment growth using linked employer-employee data for the period 2000-2010, Brändle and Goerke (2015) find a (smaller) negative effect of some 0.8 percentage points a year on the basis of cross-sectional variation. However, the use of panel and difference-indifferences estimation, as well as further controls for time-invariant heterogeneity, suggests that there is no causal effect of collective bargaining on employment growth-the cross-sectional result seemingly reflecting negative selection into collective bargaining. The conclusion that German collective bargaining has no causal effect on employment growth may be interpreted as an absence of adverse effect and viewed as positive. But, as the authors themselves note, the fact remains that this study does not provide indications of the cause of country differences such as different industrial relations systems. Given the outcome indicator, there is also the issue of differences in time periods studied and in particular the role of Germany's resurgent economy after 2000.

The results of this section may be summarized as follows. First, unionism is associated with wage rigidity that constrains labor market (re)allocation, even if firm surveys suggest this is largely the case when labor contracts are signed at higher bargaining levels. Unions also seem to facilitate the use of alternative labor cost-cutting strategies. The importance of internal labor markets should not be underplayed, survey evidence again indicating that employers attach more importance to the internal wage structure when deciding on hiring pay, even if this tendency is more pronounced in union regimes. Although the survey evidence places emphasis on the finding that wages are more flexible when bargaining is decentralized (i.e., conducted at lower levels), these other considerations have also to be borne in mind together with the recognition that the manner in which the institutions of collective bargaining and worker representation are incorporated is rudimentary. Meantime, recent theoretical developments in the areas of collective voice and contract theory envisage a potentially pro-productive role for unions in aggregating worker preferences in the provision of workplace public goods and in facilitating efficient contracting in situations where there is a long-term relation between worker and firm but where employers' ex ante promises to 
take workers' interests into account are not credible and where the reputation effects mechanism is weak. They caution that rigid nominal contracts may after all have a positive efficiency role.

Although objective data for the USA would-to understate the case-indicate that the promise of unions remains unfulfilled, other-country data give grounds for less pessimism. Some of the more promising results are reported for the German dual system of sectoral bargaining in combination with workplace codetermination. Even if the German evidence is sui generis, given that nation's unique institutions, we would note that sequential declines in the "disadvantages of unionism" are reported for Britain's decentralized collective bargaining system in tandem with legislation limiting union authority-material union-induced performance deficits in Britain in the 1980s being conventionally ascribed to multi-unionism. Research on high-performance work practices in the USA, Germany, and Britain also often sees unionism in a more favorable light, although the empirical literature is frankly opaque on the union role as it is on the efficacy of the transformative labor relations practices themselves.

Finally, there is historical support for the Nordic model in achieving reallocation while maintaining low unemployment. In a very real sense, there is some correspondence here with the outcome of the Anglo-Saxon model, although the respective collective bargaining systems differ greatly as do the mix of other labor market institutions. Equally, cohesion or trust may link the very different German and Nordic models, albeit in different ways, and distinguish both from the British situation if one buys into Marsden's (2015) interpretation of that nation's work system as lean and managerial directed, as opposed to Germany's high-discretion learning model of work organization (see Exhibit 1).

\section{Macro flexibility and collective bargaining}

In this section, we turn to the role played by collective bargaining institutions in achieving macro flexibility. We first provide a review of the evidence on the contribution of bargaining structure to the building blocks of full employment and the ability of the economy to respond appropriately to macroeconomic shocks. In this initial, firstpass procedure, we seek to establish the state of play in mainstream research roughly up to the Great Recession. But since this research glosses over major changes in the architecture of collective bargaining-namely a process of ongoing, even heightened, decentralization, we have also to provide a finer dissection of the framework of collective bargaining. Here, we shall use Visser's (2013) pioneering attempt to achieve comparability across time and countries of key institutional features as an organizing device on which to hang some more recent research, specifically controversies/findings on collective bargaining coverage under extension agreements, the costs of those agreements, and the impact of contract innovation under decentralization. We shall also use that framework to revisit the theoretical controversy over the bargaining level. We conclude with some thoughts on the "competitiveness" of bargaining structures as suggested in recent research.

\subsection{A broad brush initial approach}

Macro flexibility is equated with the ability of the economy to maintain a low unemployment rate in the face of macroeconomic shocks. According to Blanchard et al. 
(2013, p. 10), such flexibility has two dimensions: a low average unemployment rate and modest fluctuations in the unemployment rate in response to shocks.

There is a very large literature on the effects of collective bargaining on the level of unemployment. The early literature examined the link between union density or coverage as indicators of the degree of union monopoly power in the market and unemployment (and inflation), and adverse union effects were reported from the outset. Very soon, however, the union measure became more nuanced to reflect the structure of bargaining and the internalization of external wage effects-not just the simple exertion of market power. Internalization effects stem from the realization among unions in more centralized bargaining regimes that their wage increases will affect the price level that their members face, as well as unfavorable unemployment development and a loss in competitiveness. Accordingly, they will be less aggressive in their wage demands and take into account the macroeconomic implications of wage negotiations. The more decentralized the bargaining, the less wage externalities will be internalized. Accordingly, a straight-line relation between the degree of centralization of bargaining and economic outcomes was mooted: negative in slope for unemployment and positive for real wages. This centralization argument ${ }^{6}$ was challenged by the hump-shape thesis of Calmfors and Driffill (1988), which emphasized the importance of product market effects, leading to differences in the ability to pass on wage increases through higher prices. Decentralized bargaining implies highly elastic demand curves, so that competitive pressure from other firms in the same industry producing like goods now makes for moderation in wage demands. Just as with fully centralized bargaining, the costs cannot be passed on to others. But this is not the case, so the argument runs, for industrylevel bargaining which produces the worst outcome of all for the economy. Here, the possibility for passing on wage increases is greater since all competing firms are affected equally by the wage hike and customers cannot so easily shift their patronage to other sectors. Hence, the hump, occasioned by intermediate levels of bargaining (as represented by sectoral bargaining), delivers the worst unemployment and inflation performance. ${ }^{7}$

However, bargaining structure is a more complicated construct than (degree of) centralization, and research was soon to argue that the coordination of industry-level bargaining across the economy can serve as the functional equivalent of centralized bargaining. Thus, as noted by Traxler and Brandl (2009), none of the industry-level bargaining units can externalize the costs of wage hikes if their pay policies are coordinated. Indeed, to take up an issue that will be investigated later, coordination may be feasible at lower levels of bargaining, if, as in Japan, employer associations and national unions are vested with the authority to provide the requisite guidance to their constituent members. Notions of bargaining coordination tended to supplant prior models of the covariation of unionism and unemployment, notwithstanding the more obvious difficulties of measurement (than for union density, coverage, or even centralization). In terms of findings, despite some early results suggesting that countries with coordinated bargaining structures experienced lower equilibrium unemployment rates (e.g., Nickell 1997), the overall evidence is mixed. Aidt and Tzannatos (2008) provide a summary of 28 studies and 174 sub-studies investigating the effects of coordination on a variety of outcome indicators to include unemployment. The measure of coordination varies widely across studies, and in consequence, the ranking of countries also varies. On a simple head count, $45 \%$ of the sub-studies support the view that coordination works, although the strength of the correlation between coordination and the outcome indicator 
varies considerably - the results are clearest for the wage distribution where there is strong evidence that greater coordination is associated with lower wage dispersion (on which more in Section 6). Moreover, with the progression from simple correlations through regressions using cross-country data to regressions employing pooled cross-country data (and a sprinkling of fixed effects specifications), the results in favor of the coordination thesis weaken and the harder it is to detect a relationship between bargaining coordination and economic performance. Another commonality noted by Aidt and Tzannatos is that coordination benefits, where observed, are more likely in the 1970s and the 1980s than in the 1990s (see also OECD 1997).

At the price of some oversimplification, ${ }^{8}$ these results briefly summarize the state of play in research on collective bargaining and unemployment up to the present century and before the Great Recession and therefore prior to a somewhat finer dissection of its role (recognition of which is one main task of the present treatment). The (pre-contemporary) context is the rise in unemployment between 1960 and the mid-1990s and the heterogeneity of individual country experiences. As Blanchard and Wolfers (2000) note, shocks in the form of a productivity slowdown and adverse shifts in labor demand can offer a potential explanation for the rise in unemployment but not cross-country differences because shocks display insufficient heterogeneity, while for their part, labor market institutions can potentially explain cross-country variation but not the rise in unemployment by reason of their broad stability. Blanchard and Wolfers offer an explanation for both stylized facts: the interaction between economic shocks and labor market institutions. Specifically, the authors' regression analysis indicates that union density amplifies the adverse effect of shocks while coordination materially reduces the impact of shocks. It might therefore seem that one has an explanation for the strangely disappearing effects of bargaining coordination noted earlier: coordinated systems are more able to react to, or otherwise absorb, shocks-the supply shocks of the 1970s and the disinflationary policies of the 1980s-than they are to leverage more stable environments such as the 1990s.

Unfortunately, all labor market institutions are subject to change (and not just the replacement rate and employment protection indices used by Blanchard and Wolfers in some specifications), and the use of time-invariant measures of union density and coordination are a cause for concern. Interestingly, a more recent analysis by Nickell et al. (2005) of unemployment development in the OECD countries over the same interval, now using annual data rather than the 5-year averages used by Blanchard and Wolfers, fully incorporates time-varying institutions. The authors report that as much as $55 \%$ of broad movements in unemployment across the OECD nations can be explained by shifts in labor market institutions. However, interactions between average values of these institutions and shocks, now captured by time dummies, do not add materially to the explanation of changes in unemployment. Nevertheless, in common with Blanchard and Wolfers and some more recent research (e.g., Bowdler and Nunziata 2007), coordination is found to mitigate the harmful effect of union density on unemployment.

\subsection{Dissecting changes in collective bargaining and decentralization}

Despite the economist's indicators of labor market institutions being fixed for often considerable periods of time, each is in reality time varying. Of late, this seems even more the case for collective bargaining institutions, the Great Recession and its 
aftermath marking the most recent interval of flux (see Visser 2013, 2016; Addison et al. 2016b). In this section, we set the scene for our diagnosis by tracing some of the more important developments in collective bargaining in advanced industrial nations. Drawing extensively on Visser (2013), we organize our discussion around the three dimensions of bargaining coverage, bargaining structure, and bargaining coordination.

\subsubsection{Bargaining coverage}

Bargaining coverage is widely held to be a more adequate expression of the degree of collective organization than union density. Major differences between the two measures are accounted for by extension agreements, considered below. Coverage and density rates for a sample of advanced industrial countries are provided in Table 1 for the years 1995-2010/2013. Not shown in the table are the long periods of stability in coverage for European nations up to the 1990s after which point there has been some slippage. For its part, the decline in density started much earlier and has been more dramatic, as the data in the final column of the table testify. The link between density and coverage though positive is fairly weak. More important is the link between multi-employer bargaining and coverage.

Countries in the table are organized according to whether bargaining is predominantly sectoral (in the upper panel of the table) or firm/enterprise based (lower panel). The

Table 1 Changes in bargaining coverage and union density, 1995-2010, and in density since peak

\begin{tabular}{|c|c|c|c|c|c|c|c|c|c|}
\hline & \multicolumn{4}{|c|}{ Bargaining coverage (\%) } & \multicolumn{5}{|c|}{ Union density (\%) } \\
\hline & 1995 & 2010 & 2013 & Change & 1995 & 2010 & 2013 & Change & Change from peak \\
\hline Austria & 98.3 & 99.0 & 98.0 & 0.7 & 41.1 & 28.4 & 27.4 & -12.7 & $-56.8(1960)$ \\
\hline Belgium & 96.0 & 96.0 & 99.0 & 0.0 & 55.7 & 50.6 & 55.4 & -5.1 & $-9.2(1995)$ \\
\hline Germany & 76.0 & 61.1 & 57.6 & -15.0 & 29.2 & 18.6 & 17.7 & -10.7 & $-48.3(1991)$ \\
\hline The Netherlands & 82.3 & 84.3 & 84.8 & 2.0 & 25.7 & 18.6 & 17.6 & -7.0 & $-50.8(1960)$ \\
\hline Switzerland & 41.7 & 49.1 & 48.6 & 7.3 & 22.7 & 17.2 & 16.2 & -5.5 & $-52.4(1960)$ \\
\hline Finland & 85.0 & 89.5 & 93.0 & 4.5 & 80.4 & 70.0 & 68.6 & -10.5 & $-13.3(1993)$ \\
\hline Sweden & 94.0 & 91.0 & 89.0 & -3.0 & 83.1 & 68.4 & 67.7 & -14.7 & $-21.2(1994)$ \\
\hline Norway & 72.0 & 74.0 & 66.9 & 2.0 & 57.3 & 54.8 & 63.5 & -2.5 & $-9.9(1961)$ \\
\hline Denmark & 84.0 & 85.0 & 84.0 & 1.0 & 77.0 & 68.5 & 66.8 & -8.4 & $-24.8(1987)$ \\
\hline Italy & 85.0 & 85.0 & 80.0 & 0.0 & 38.1 & 35.5 & 36.9 & -2.6 & $-29.7(1976)$ \\
\hline Spain & 80.0 & 73.2 & 79.1 & -6.8 & 16.3 & 15.6 & 17.5 & -0.8 & $-16.6(1980)$ \\
\hline Portugal & 94.0 & 80.0 & 67.0 & -14.0 & 25.4 & 19.3 & 20.5 & -6.0 & $-64.8(1980)$ \\
\hline Greece & 65.0 & 65.0 & 40.0 & 0.0 & 31.3 & 25.4 & 21.3 & -5.9 & $-34.9(1980)$ \\
\hline France & 90.0 & 92.0 & 98.0 & 2.0 & 7.90 & 7.90 & 7.70 & -0.9 & $-64.4(1969)$ \\
\hline Luxembourg & 60.0 & 58.0 & 59.0 & -2.0 & 43.5 & 37.0 & 32.8 & -6.5 & $-20.9(1970)$ \\
\hline Australia & 70.0 & 45.0 & 61.0 & -25.0 & 32.1 & 18.0 & 17.0 & -14.1 & $-64.1(1976)$ \\
\hline Ireland & 40.0 & 42.2 & 32.4 & 2.2 & 48.1 & 33.5 & 29.6 & -14.6 & $-42.8(1978)$ \\
\hline UK & 36.0 & 30.8 & 29.5 & -5.2 & 33.1 & 26.5 & 25.4 & -6.6 & $-47.7(1978)$ \\
\hline Canada & 36.7 & 31.6 & 29.0 & -5.1 & 33.7 & 27.4 & 27.2 & -6.3 & $-16.4(1984)$ \\
\hline Japan & 21.5 & 16.0 & 19.6 & -5.5 & 24.4 & 18.4 & 17.8 & -6.0 & $-48.2(1964)$ \\
\hline New Zealand & 43.3 & 17.0 & 15.0 & -26.3 & 27.2 & 20.8 & 19.4 & -6.4 & $-69.9(1980)$ \\
\hline USA & 16.7 & 13.1 & 11.9 & -3.6 & 14.3 & 11.4 & 10.8 & -2.9 & $-63.1(1960)$ \\
\hline
\end{tabular}

Sources: Visser (2013); Schnabel (2013); Pontusson (2013); OECD.Stat. Figures in italics indicate corresponding values for 2013. Peak year given in parentheses 
balance of the countries (middle panel) has mixed systems. Under firm-level bargaining, declines in union density translate into declining coverage. Under sectoral bargaining, employers cannot easily escape collective agreements by switching to a non-union regime while remaining in the same sector. The most dramatic reductions in coverage rates have therefore attended a collapse of multi-employer bargaining and its replacement by singleemployer bargaining (the UK in the 1980s) and the withdrawal of government support for multi-employer bargaining (New Zealand after 1991 and Australia after 1996). Note that multi-employer bargaining depends importantly upon effective employer organization. ${ }^{9}$

In discussing coverage, an important issue is extension agreements. In a good number of continental European nations, high levels of union coverage of $75 \%$ or more are achieved through a combination of sectoral (or higher) level bargaining, strong employer organization, and a widespread use of procedures for extending the terms of collective agreements. Of these, the most important is administrative extension, whereby at the request of the parties the relevant government entity confirms the extension based on the terms of ruling agreements (or sometimes "enlarges" collective agreements to sectors than have no collective agreements).

Unsurprisingly, administrative extension is often requested by unions in decline as a form of revitalization from above. Equivalently, the collapse of collective bargaining in New Zealand can be directly attributed to the abolition of statutory wage-fixing machinery and with it the extension procedures used to implement national awards of that nation's Court of Arbitration. (Note that the arrangement whereby uncovered firms "orient" themselves to a collective agreement is briefly addressed below as a special case because it is not underwritten by law.) Also, as a referee reminded us, the history of the institutions of extension is that small- and medium-sized employers, and a coalition of Christian unions and parties, have pursued extension as a means of promoting selfregulation through collective bargaining and mitigate or lessen class conflict.

The case against extension arrangements was made forcefully in the OECD Jobs Study (OECD 1994) where it was proposed that administrative extension of agreements that impose inflexible conditions should be phased out. Its main objections were twofold. First, extension was seen as relaxing the constraints on unions while, second, making employers more willing to accede to exaggerated wage demands. Employers may of course also favor extension as a means of preventing underbidding, the most recent example of this in a European context being the case of cross-border service provision. Requiring foreign service providers to meet domestic standards, as under extension laws in Denmark and Switzerland or as the basis for minimum wages in specific sectors as in Germany, may also be viewed as supportive of insider coalitions, but the more general point is that extension serves a number of different purposes, including the creation of common standards or funding of apprenticeship, training, and preretirement (Visser 2016, p. 6). As a practical matter, the OECD position has softened in subsequent policy statements (e.g., OECD 2004) on the reasoning that unions might seek moderate wage increases in circumstances where they implicitly have to represent the views of all workers in a sector rather than more privileged groups for whom the unemployment risk is already attenuated. In other words, wage claims might be finessed in anticipation of their generalization under extension arrangements.

Both positions are reflected in the analysis of Blanchard et al. (2013) who argue on the positive side of the ledger that, in sectors where there are a large numbers of small 
firms, transaction costs might preempt bargaining ab initio and also that extension arrangements might rule out, or at least lessen, incentives to undercut reasonable wages and working conditions. On the negative side, however, Blanchard et al. (2013, p. 12) accept that: "At times, by allowing workers to benefit from bargaining outcomes even if they are not union members, they may decrease the representativeness, and by implication the legitimacy, of unions and, by so doing, decrease the quality of industrial relations" (see also Flanagan et al. 1993, p. 424). The authors also recognize that flexibility might be impaired by extension procedures given productivity difference between firms, leading them to recommend temporary opt-outs for firms needing time to adjust as well as what they describe as "top-ups" for the most profitable enterprises.

Based on the procedures, scope, and conditions surrounding extension arrangements, Visser (2013, Table 4) has provided a classification of extension regimes for a sample of 26 European countries plus Australia, Canada, New Zealand, and the USA (where, as in the UK and Ireland, extension mechanisms are in most cases absent). ${ }^{10}$ In addition to extension procedures per se, he notes a second "trajectory" offering very high coverage rates of $75 \%$ or more that is found only in Scandinavia. It comprises sectoral (or national) bargaining and a high union density that can force non-unionized employers into line. Unlike the former combination of sectoral bargaining-strong employer organization-extension arrangements, which hinges on state support, this second trajectory rests upon a continuing organizational capacity on the part of unions. Given the reality of union decline, he concludes that high coverage rates will continue to depend on public intervention or at least a non-reversal of policies of open or tacit support for collective bargaining. He is pessimistic on this score, noting the dramatic effects of changes in public policy in the UK and New Zealand and Australia, recent events in countries depending on international financial assistance (Greece, Portugal, and Ireland) that are stated to have had a cooling effect on collective bargaining, plus developments in the new EU member states (the Baltics, Poland, and Hungary) where weak unions tempt employers to abandon collective bargaining.

This brings us to the issue of the costs of extension agreements. We earlier noted a qualified softening of the position of the OECD inter alia against extension agreements conditional on such factors as the representativeness of the social partners and the dispersion of productivity between firms. Note, however, that in the case of Portugal, the OECD (2012) flatly rejected extensions and recommended that they be abolished in their entirety. The OECD reasoned that extensions were used by dominant firms to impose higher wages and working conditions on others, reducing competition and entry in the process.

Our two case studies in Exhibit 2 suggest that extending contracts potentially has large costs in terms of employment destruction, albeit "modified" by increased labor market segmentation, and in amplifying aggregate shocks. These costs can be mitigated by (higher) representativeness thresholds, which can in principle preserve the usefulness of extension agreements such as preventing the undercutting of reasonable employment standards and sustaining collective bargaining. Another option would be to allow firms in difficulties to opt out, by exact analogy with opening clauses. (A more general analogy is the rule in Germany exempting the long-term unemployed from minimum wage legislation for the first 6 months of their employment.)

Two other possibilities, noted by Villanueva (2015, p. 9), would be to make extensions non-binding once a collective agreement has expired and even to switch to an 
Exhibit 2 The costs of extension agreements: the "unhappy" cases of Portugal and Spain

Two recent studies have sought to examine the costs of extension arrangements for two countries recording among the greatest disparities between union density and coverage, namely Portugal and Spain. Beginning with Portugal, Martins (2014) evaluates the impact of extensions in terms of the employment and wage bills of the affected sectors using a difference-in-differences approach. Employment equations for the sample period 2007-2011 are estimated. Specifically, industry employment is regressed on a dummy variable for extensions (set equal to 1 in the first 4 months after the extension of the collective agreement in that industry comes into force, 0 otherwise), controlling for industry and time fixed effects. In addition to employment, Martins presents corresponding regressions for hires, separations, and the wage bill. He reports that the average number of workers employed in an industry falls by $2 \%$ in the 4 months following an extension. The employment result is produced by a fall in new hires of $4 \%$, while separations are unaffected. In sharp contrast, service providers for the industry from the informal sector-and as such not subject to the extensions' wage floors or indeed any other rules of the labor code-see their employment rise by $1.4 \%$. The latter increase falls well short of that required to match the loss of formal employment, noted earlier. The total wage bill falls on average by $2.2 \%$ following extensions.

Moreover, Martins shows that his results are robust to more detailed timing effects, different ways of controlling for time differences, firm types (although small firms with less than 10 employees record higher employment losses of $2.6 \%$ ) and broad sector, and alternative counterfactuals. He also conducts a falsification test based on extensions that were announced but not implemented. He finds that only those extensions that become legally binding have negative employment effects. The bottom line of this study of almost 30,000 de facto minimum wages - one for each main job in each industry -is sobering, namely a fall in sectoral employment and wage bills of $2 \%$ and a growth in segmentation. Another very recent study investigating sectoral wage contracts that are automatically extended provides corroboratory evidence on disemployment costs for Spain. Díez-Catalán and Villanueva (2014) examine contracts signed immediately before and immediately after the bankruptcy of Lehman Brothers on September 15, 2008, an event presaging a large and unexpected drop in economic activity. They report that the former wage increases exceeded the latter by 1 percentage point. This wage adjustment happened within industries and provinces given the regional nature of collective bargaining in Spain. Some 2 years after this event, workers in firms covered by the earlier contracts had a 1 percentage point greater probability of being unemployed than their counterparts covered by the later contracts.

Matching information on collective contracts with longitudinal data from a $4 \%$ sample of Spanish Social Security records, and selecting those whose wages grew most-individuals whose monthly earnings in December 2007 were at most 1.2 times the minimum wage in the agreement-it was found that the differential increase in the probability of not working in March 2009 among workers whose collective contract was signed before the Lehman bankruptcy fluctuated between 3 and $4 \%$ in late 2010. The wage increase among job stayers with wages close to the minimum was $2.86 \%$. Vulgo: earnings losses among those who lost their jobs offset the wage gains of those who remained in work.

opt-in system of collective bargaining, whereby sectoral or higher-level bargaining collective agreements would make provision for non-negotiating and therefore nonsignatory firms to sign on to an agreement ex post after the negotiation. However, the latter recommendation may be criticized as ignoring the point that foreclosing underbidding may be a precondition for sectoral collective bargaining in the first place, returning us to exemption based on ex ante defined criteria (on which more below). For its part, the former recommendation returns us to Exhibit 2. As our description of the Portuguese and Spanish experiences with extension as "unhappy" is meant to imply, one should distinguish between systems with automatic extension and the rest. More 
specifically, the issue here is the frequency of procedures regulating the "after effects" of collective agreements beyond their expiration. Such procedures are not the norm.

There are two further issues. First, although we have perforce neglected other labor market institutions in this treatment, the first harks back to the interaction between extension agreements and other labor market policies (or indeed their absence). One obvious factor is the tax wedge, namely the difference between the cost of an employee to the firm and take-home pay. In analysis of 15 OECD countries, 1965-2007, Murtin et al. (2014) report that the adverse effect of the tax wedge on unemployment is large in countries with liberal extension procedures (such as France and Spain) and minimal in nations where extension is limited or absent (Scandinavian nations). Second, in nations where extension is vestigial, there is the issue of whether the coverage statistics are downwardly biased in circumstances where uncovered (i.e., non-union) firms "shadow" collective agreements in setting wages. Germany is often cited as a classic case in point. However, recent research does not suggest that such "orientation" practices constitute an important source of undercounting (see Addison et al. 2016a).

\subsubsection{Bargaining structure}

The decentralization of collective bargaining is a hallmark of industrial relations since the 1980s and can be considered as equal in importance to deunionization. That is, national (i.e., cross-industry/intersectoral) bargaining has tended to give way to sectoral bargaining while local or enterprise bargaining has gained in prominence either by replacing sectoral bargaining or by acting as an additional layer of bargaining. Although decentralization has generally been welcomed by theorists, there remains sharp disagreement as to the preferred variant(s) that will be examined in the next subsection.

Visser (2013) has offered a careful discussion of decentralization in which he distinguishes between the principal level at which collective bargaining takes place, a process of devolution within central or sectoral agreements whereby more issues are settled at the local level, and the existence of use of opening clauses or "derogations" from the terms of collective agreements. He also offers a composite indicator of decentralization, summing scores along each of these three dimensions.

Beginning with the bargaining level, Visser derives a five-point scale in which company or enterprise level is considered the lowest level $(=1)$ and where central or cross-industry bargaining with centrally binding norms is the highest level $(=5)$. Since industry or sectoral bargaining is given an intermediate score $(=3)$, it follows that there are two mixed situations between levels (5) and (3) and between (3) and (1). The next requirement is the identification of a dominant bargaining level which is fixed at two thirds of the privatesector coverage rate. As of 2000+ and abstracting from the eight Central and Eastern European (CEE) member states, where company bargaining dominates (in six cases), he obtains the following distribution of countries by the bargaining level: (a) company/enterprise-level bargaining dominates-Ireland, the UK, Japan, Canada, the USA, and, since the 1990s, New Zealand; (b) sectoral bargaining dominates-Austria, Belgium, Finland, Germany, Greece, Italy, the Netherlands, Norway, Spain, Portugal, Sweden, and Switzerland, with Denmark being a borderline case given its material amount of company-level bargaining; and (c) mixed cases-Luxembourg, Australia, and France with an equal share of company and industry bargaining (see also Visser 2016, Table 3).

Some noticeable trends include the special cases of decentralization from centralized cross-industry bargaining in the Scandinavian group of nations, although the sister Nordic 
country, Finland, has since returned to the fold of centralized, tax-based income policies; the dramatic changes in Ireland from centralized bargaining under successive regimes of social pacts to a restoration of company-level bargaining after 2009; and the opposing trends toward and away from central bargaining in Belgium and the Netherlands, respectively. ${ }^{11}$ Comparing the frequencies of dominant bargaining levels over the interval 1960-2010, it is the case that industry bargaining which had come to dominate by 1980 has continued to do so in Western European nations. That said, the importance of enterprise bargaining in the large majority of the CEE nations gives primacy to that form of bargaining on a head count of the 30 nations in Visser's sample. For its part, centralized bargaining is not entirely a thing of the past, given the nature of the national agreement in Greece in 2010, its resurrection in Finland, and government restrictions on wage increases in Belgium.

But, as was noted earlier, the diversity in sectoral bargaining arrangements means that any classification of bargaining structure based solely on the bargaining level is hazardous and assuredly insufficient to address decentralization. Visser's amplification of bargaining structure next turns to a distinction between two-level or two-tier bargaining and single-level bargaining. This distinction does not apply only to sectoral bargaining, however, since centralized agreements may involve just a single level or allow for additional bargaining on pay.

In discussing multi-level bargaining, Visser sees the key distinguishing characteristic to be one of articulation, which is defined as the extent to which additional bargaining on pay is under control of the union, and regulated and defined by the sectoral (or central) agreement and subject to a peace clause. So the critical issue here is said to be governance capacity. Two-tier systems are seen as operating within Belgium, Denmark, Greece, Italy, Norway, Spain, and Sweden. (Single-level multi-employer bargaining models, where as a rule no local bargains are assumed to obtain, include Austria, Germany, Finland, France, the Netherlands, and Switzerland.) Again, on the basis of a ranking exercise, Visser's conclusion with regard to systems with a systematic second bargaining round-the so-called institutionalized two-tier bargaining-is that while multi-level bargaining has increased over time, fully articulated bargaining is rare. The contemporary poorly articulated counterparts of Britain and Italy in the 1970s and 1980s are identified as Spain, Portugal, Greece, and Spain.

Another aspect of decentralization is opening clauses, which are of especial interest as they permit the setting of less favorable wages and working conditions at the local level than were fixed under higher-level agreements-typically at the sectoral level. These include not only (one-time) hardship agreements which are exceptional and temporary and designed to avert impending insolvency or major job loss but also opening clauses or optout arrangements that, while also seeking to apply contracts in ways less favorable than what has been agreed to at a higher level, are more general in the sense that they are no longer tied to exceptional circumstances and not necessarily reversible in the next contract period. Such opt-out clauses have in practice been both conditional on approval by the collective bargaining parties or applied without such a condition.

The German experience with opening clauses is the best known, not least since such agreements have become institutionalized. Initially, opening clauses were concerned with working hours, including the accommodations that had to be made in the wake of negotiated reductions in working hours and partly as a result of which negotiations involved workplace flexibility. Subsequently, opening clauses became concerned with pay. And latterly, they have in part morphed into pacts for employment and competitiveness that take on the characteristics of integrative bargaining. Case studies of opening clauses 
Exhibit 3 Decentralization and economic outcomes: two case studies for Germany

(a) Opening clauses and employment

Brändle and Heinbach (2013) see opening clauses as a means of arresting the decline in coverage and increasing employment in covered firms. Specifically, they argue that opening clauses allow employers to reduce wages in the event of negative shocks, with different effects on job flows according to whether the clauses are applied. For firms applying such clauses, job destruction should decline on account of their being able to retain a larger number of employees and, to the extent that they reduce job creation with improvements in the economy, their job reallocation rates should be lower. On the other hand, firms not applying opening clauses could increase job creation in anticipation of their increased flexibility and if the economic situation worsens be able to avoid job destruction. On balance, the economy should register higher job growth by virtue of improved decision-making on the part of firms.

To investigate the employment issue, the authors use information on opening clauses from the Institute of Applied Economic Research (IAW) Data Set on Opening Clauses and the IAB Establishment Panel, 2000-2007. The outcome indicators examined are job flows: job creation, job destruction, job reallocation (viz. the sum of job destruction and creation), and job growth. As a first step, the authors use propensity score matching to control for selectivity bias and thence measure the average treatment effect on the treated observations, conditional on the respective propensity scores, to identify the effect of opening clauses on job flows.

It is reported that establishments whose collective bargaining agreements contain opening clauses have lower job reallocation rates, lower job destruction rates, and higher job growth rates-only job creation is unaffected by opening clauses. It is argued that the lower job destruction rates indicate that opening clauses fulfill their objective of giving firms more flexibility to save jobs in harsh economic times, even if establishments do not appear to anticipate the increased flexibility (i.e., by hiring a larger number of workers).

The authors then test the latter argument by examining the effect of knowledge of opening clauses on job flows. Explicit knowledge of opening clauses is shown not to affect job flows, and the job growth rate remains statistically insignificant, leading the authors to conclude that establishments do not gain more flexibility from opening clauses - or perhaps already have enough flexibility as might be the case if they pay above the bargained wage.

Finally, they consider job flows in establishments that actually apply opening clauses as opposed to simply having such clauses in their framework agreements. There is no indication that job flows are significantly impacted; that is, although the existence of opening clause seems to reduce job destruction rates, the application of opening clauses shows no additional effects. The authors speculate that this may reflect the role of the works council since the application of such clauses is secured through negotiation with that entity. As a practical matter, however, opening clauses are also applied in establishments without works councils. A recent study by Ellguth et al. (2014) of opening clauses using the 2005 and 2007 waves of the IAB Establishment Panel sheds further light on this issue. They report that (a) the existence of opening clauses is associated with higher wages (a sort of quasi-insurance premium) while (b) their application results in wage cuts of approximately similar magnitude that (c) works council establishments are able to resist.

(b) Pacts, employment, wages, investment, labor productivity, innovation, and business survival

The existing literature on pacts for employment and competitiveness presents a mixed picture largely restricted to employment effects. A recent study by Addison et al. (2015) investigates the association between pacts and a much wider range of outcomes, namely wages, productivity, innovation, and survivability in addition to employment. Using data from the IAB Establishment Panel for the core interval 2006-2009, the authors compare outcomes in establishments that successfully negotiated such agreements with those plants where the outcome of negotiations 
was unsuccessful. The assumption made is that the negotiation outcome is equally uncertain on the left and right margins of the decision threshold since the data do not contain information (i.e., "votes") that would enable us to determine whether those establishments with pacts were actually on the brink of not signing an agreement and whether those that failed to sign a pact having begun negotiations were sufficiently close to signing an agreement. Indicative regression results for 1-, 2-, and 3-year treatment effects are first reported for four different specifications of the model that assume local randomization are first provided. Abstracting from results for the baseline specification, in 10 out of 45 cases, the estimated pact coefficients are positive and statistically significant while in the remaining cases, one cannot exclude a zero impact on performance. For the preferred specification, there are three key findings: first, a 2-year effect of about $8 \%$ in an establishment's average wage; second, a 3-year effect on establishment productivity of approximately $20 \%$; and, third, a 1-year effect on innovative activity of some $11 \%$.

In the first of two robustness checks, the authors randomize participation of "individuals" in the treatment and control groups. They next assign a random sampling probability to each unit in the original treatment and control groups, followed by a weighted regression in which the weights are given by the inverse of the allocated probability. The authors' simulations are centered around the point estimates for the key outcome indicators. In other words, higher wages, enhanced productivity, and improved innovation survive the robustness checks. The bottom line is that pacts seemingly fulfill an integrative bargaining function and are to be distinguished from old-style concession bargaining.

and pacts are contained in Exhibit 3. Table 2 provides descriptive information on the spread of opening clauses and pacts for employment and competitiveness in Germany using unweighted data.

Focusing here on the issue of pay concessions, it is clear that decentralized wage bargaining proper may involve counterparts to opening clauses. Visser identifies arrangements in Denmark, Sweden, Norway, Switzerland, and the Netherlands as cases in point. In countries such as Sweden and Denmark, opening clauses are described as "generalized," in the sense that local bargaining controls much more of total earnings, more of which is tied to performance. In Norway, on the other hand, the use of opening clauses has been sporadic. The same is true of the Netherlands and Switzerland, where the clearest examples of formal opening clauses are from the past rather than contemporary in nature. While noting that this is also true of Austria, Visser cites the more recent case of the location clause contained in the 2011 metalworkers' collective agreement that permits poorly performing companies to divide the collectively negotiated wage increase into a general part and a contingent, individual performance-related component.

France, for its part, is something of a sport given the unimplemented components of collective agreements, exemptions to minimum wage agreements, the much larger role of variable pay, and the generally increased autonomy of the firm from the wider industrial relations system. All such developments display features analogous to opening clauses.

Southern Europe also remains something of an exception given what Visser (2013, p. 50) refers to as the "hierarchical layering of agreements based on the favorability principle." That said, he notes inter al. an Italian central agreement of 2011 permitting enterprise agreements to introduce temporary and experimental modification of the provisions in sectoral agreements; a Spanish framework agreement of 2012 allowing extended use of opening clauses on working time, pay systems, and work organization in the event of a persistent decline in revenues; and Greek legislation of 2010 allowing 
Table 2 The presence of company-level pacts and opening clauses in Germany (in percent of employment)

\begin{tabular}{|c|c|c|c|c|c|c|c|c|c|}
\hline Year & Pacts $^{a}$ & $\begin{array}{l}\text { Opening } \\
\text { clauses }^{\mathrm{b}}\end{array}$ & $\begin{array}{l}\text { Pacts in establishments } \\
\text { with opening clauses }\end{array}$ & $\begin{array}{l}\text { Opening clauses } \\
\text { in establishments } \\
\text { bound by a collective } \\
\text { agreement }\end{array}$ & $\begin{array}{l}\text { Pacts in establishments } \\
\text { bound by a collective } \\
\text { agreement }\end{array}$ & $\begin{array}{l}\text { Pacts in establishments } \\
\text { without collective } \\
\text { agreements }\end{array}$ & $\begin{array}{l}\text { Pacts in establishments } \\
\text { using opening clauses }\end{array}$ & $\begin{array}{l}\text { Use of opening clauses } \\
\text { in establishments } \\
\text { bound by collective } \\
\text { agreements }\end{array}$ & $\begin{array}{l}\text { Use of opening clauses } \\
\text { in establishments with } \\
\text { opening clauses }\end{array}$ \\
\hline 2005 & 31.6 & 37.2 & 49.3 & 43.2 & 35.3 & 8.4 & 59.6 & 24.1 & 56.0 \\
\hline 2006 & 31.0 & 29.8 & 57.1 & 42.2 & 34.5 & 7.4 & & & \\
\hline 2007 & 30.1 & 37.5 & 45.7 & 44.9 & 34.7 & 6.7 & 51.2 & 24.7 & 55.1 \\
\hline 2008 & 30.6 & 30.4 & 49.0 & 39.9 & 35.1 & 7.4 & & & \\
\hline 2009 & 33.9 & 29.0 & 54.8 & 40.0 & 38.1 & 12.9 & & & \\
\hline 2010 & 21.6 & 47.4 & 38.9 & 60.6 & 25.7 & 3.5 & & & \\
\hline 2011 & 24.2 & 50.7 & 40.2 & 62.1 & 28.5 & 3.8 & 44.6 & 48.9 & 78.8 \\
\hline 2012 & 24.7 & 48.4 & 43.2 & 62.8 & 29.3 & 4.7 & & & \\
\hline 2013 & 27.1 & 46.5 & 49.9 & 61.5 & 32.0 & 5.1 & & & \\
\hline
\end{tabular}

Source: author's calculations. The reported sample probabilities are based on the annual IAB Establishment Panel (IAB-Betriebspanel), 2005-2013, unweighted data

${ }^{a}$ Questions on pact status are asked in the 2006, 2008, 2009, and 2013 waves of the IAB Establishment Panel

${ }^{b}$ Questions on opening clause status are asked in the 2005, 2007, and 2011 waves of the IAB Establishment Panel 
company agreements to derogate from the terms and conditions of sectoral agreements in cases of economic hardship and indeed the reforms of 2011 that reversed the hierarchy of agreements, now giving precedence to the firm-level over the sectoral level. At issue, of course, is the longevity of these special arrangements.

Finally, the development of partnership agreements in Ireland and the UK, analogous to the German pacts for employment and competitiveness (see panel (b) of Exhibit 3), can theoretically play a crucial part in recasting the organization of the workplace and meeting the prime allocative requirement of flexibility. We note parenthetically that under the now defunct Irish partnership programs, inability to pay was also a factor allowing derogation from the general rounds of wage increases contained therein.

Visser's indicators of the extent to which multi-level agreements are articulated and of the scope for opening clauses (or derogations) thus provide a basis for differentiating among nations in which sectoral bargaining dominates.

\subsubsection{Bargaining coordination}

As was noted at the beginning of this section, coordination succeeded centralization as a favored construct in modeling the effect of collective bargaining on wage and unemployment outcomes. Coordination may be defined as the synchronization of the pay policies of distinct bargaining units. Unfortunately, its measurement is by no means transparent. Visser (2013) seeks to throw more light on the issue by discussing modes and extent of coordination. The former refers to the methods designed to achieve coordination and is thus not parametric. The latter offers an attempt at measurement based on expectations about institutional features that are likely to generate either more or less coordination.

The modes approach is based on Traxler et al. (2001). One such mode is state-imposed bargaining based on statutory controls, examples of which are today restricted to just Belgium and Greece. State-sponsored bargaining or social pacts (see Section 4) are an altogether more common type and have been deployed consistently in Finland and Ireland (where they have dominated recent experience) as well as the Netherlands, Italy, and Spain. A third mode, inter-associational bargaining, which refers to binding central agreements as practiced in Sweden, Norway, and Denmark in the 1980s, is today a rarity-the sole contemporary example being Spain-partly by reason of the decline in the market share of these peak organizations. Pattern bargaining, on the other hand, is a more familiar vehicle of contemporary coordination, and is dominant in Austria, Denmark, Norway, Sweden, Germany, and Japan. Intra-associational or the socalled informal coordination occurs where guidance is offered by the major union or employer confederations without agreements between themselves. Finally, an absence of coordination-the uncoordinated bargaining mode-may nevertheless exhibit coordination where there is some external influence upon wage bargaining. The classic example is the minimum wage machinery of SMIC (Salaire Minimum de Croissance) in France which shores up an entire wage structure. ${ }^{12}$

In offering a measure of coordination, Visser seeks to allow for variation in the extent of coordination within a particular mode of coordination. The upshot is that there is a positive but not overwhelming correlation between the mode or mechanism and the actual degree of coordination. This is because the highest levels of coordination are based on different mechanisms. Thus, for the top 10 ranked countries as of 1995-2010, the 
mechanisms are as follows: Belgium-state-imposed central bargaining; Finland-social pacts; Japan-pattern bargaining based on enterprise bargaining; Norway-pattern bargaining based on industry bargaining; Austria - pattern bargaining based on industry bargaining; Denmark-pattern bargaining based on industry bargaining; Sweden-pattern bargaining based on industry bargaining; Ireland-social pacts; Germany-pattern bargaining based on industry bargaining; and the Netherlands-associational coordination. An updated ranking for 2001-2014 is provided in Visser (2016, Table 4). This contains the same countries with the exception of Ireland (replaced by Luxembourg) which now joins the lowest-ranked countries by extent of coordination with the collapse of state-sponsored bargaining in that nation. That said, there is seemingly no general trend in coordination in recent years in Western Europe.

Visser's careful description of the institutions of collective bargaining along the three dimensions of bargaining coverage, structure, and coordination raises a number of issues, only some of which have been addressed thus far. The dominant theme is of course decentralization, whose development seems both incontrovertible and irreversible. While justified on flexibility grounds, however, decentralization raises two main issues. The first has to do with the appropriate model of collective bargaining. Given that coordination has been shown to be important for macroeconomic adjustment, a combination of national- and firm-level bargaining might well be indicated, although efficient forms of sectoral bargaining would seem to garner support from recent empirical findings on contract innovations made under sectoral bargaining in Germany (and perhaps under an evolving Scandinavian model as well). Second, however, decentralization can be destabilizing or disorganized, again raising the question of support from above. More bluntly, Visser's (2013, p. 65) characterization of wage-setting institutions as being in a "state of turmoil" augurs ill for trust, which may be a more critical factor for achieving macro stability than any particular bargaining structure.

\subsection{The controversy over firm-level and sector-level bargaining redux}

Some of the most recent theoretical work has focused on the advantages of decentralization, and in particular plant-level bargaining, stimulated at least in part by influential forces in Germany recommending outright decentralization or at least further decentralization of bargaining (e.g., Berthold and Fehn 1996; German Council of Economic Experts 1996). Interestingly, however, Fitzenberger and Franz (1999a, b) were to offer an early defense of the German sectoral bargaining status quo ante. Their defense rested on the incorporation of insider-outsider considerations into a theoretical model of employment in which outsiders who are unemployed in the previous period are less productive than incumbents, who are in turn assumed to carry more weight in union councils (i.e., via the union's utility function). Demand is uncertain at the time of bargaining when wages are set, and the union's wage policy determines the expected number of workers in the current period, actual employment being determined in the next period. A monopoly union model is assumed with employment being set at the firm level. Under firm-level bargaining, a union maximizes its utility conditional on the number of insiders in the firm, whereas under industry bargaining, a uniform wage is set for all firms in that branch.

The theoretical outcome of the model being ambiguous under either a myopic union scenario or its converse (i.e., where unions have a long-run orientation and take 
employment effects into account), the relative performance of the two bargaining systems with respect to the employment outcome is shown to hinge on the values of the (five) key parameters of the model. ${ }^{13}$ The authors' simulations for different values of these parameters show that industry-level bargaining can indeed outperform firm-level bargaining in circumstances where unions place greater weight on employment relative to wages and evince more of a long-run orientation in wage setting. But the result is not guaranteed. Thus, a higher relative weight of the wage in the union utility function or a higher alternative (non-union) income can swing the balance back in favor of firm-level bargaining. On this analysis, then, the superiority of industry bargaining over firm-level bargaining hinges on unions in the latter scenario seeing the gain from higher employment through wage moderation as being dwarfed in practice by the benefits from pursuing the interests of insiders.

More recent theorizing favors a fully fledged decentralization of collective bargaining. Thus, Jimeno and Thomas (2013) seek to demonstrate the superiority of firm-level bargaining from an unemployment perspective. Unemployment is taken to be the result of endogenous gross job creation and gross job destruction flows. The key to the authors' analysis of differential labor market performance is firm heterogeneity in productivity levels and wages that are alternatively determined by firm-specific productivity and sector-wide average productivity (implying wage compression). The theoretical result of the model is that unemployment is elevated under sectoral bargaining as the job destruction threshold is greater, so that low-productivity jobs that would survive/be generated in firm-level bargaining would be destroyed/not created under sectoral bargaining. Further, the anticipation of lower or zero profits for low-productivity jobs discourages vacancy posting in sectoral bargaining regimes. Given the authors' search and matching model (with Nash bargaining), it follows from the model that unemployment rates will be lower under firm-level bargaining. Furthermore, Jimeno and Thomas assess numerically the magnitude of this underperformance by calibrating their model to an average continental European economy, where the baseline is sector-level bargaining. It is calculated that the steady-state effects of moving to a firm-level bargaining scenario in which every firm bargains individually with its workers would reduce the unemployment rate by 3.2 percentage points.

Nevertheless, they also demonstrate that were it possible to (costlessly) opt out from a sectoral agreement and negotiate a new firm-level agreement in an efficient manner (i.e., where such an arrangement was mutually beneficial), the resulting job destruction and creation rates and unemployment under sectoral bargaining can mimic those of firm-level bargaining. The situation is characterized by a productivity threshold that is lower for opting out firms than for their non-opting-out counterparts and which is identical to that in the firm-level bargaining case(s). Finally, quite apart from the issue of efficient opting out, the authors recognize that the superiority of firm-level bargaining in their model depends on one single characteristic of collective bargaining and one single route (viz. wage compression). ${ }^{14}$

Another recent study by Boeri (2014) updates the bargaining framework in modeling two-tier bargaining structures, defined as multi-employer agreements that coexist with supplementary plant or firm-level single-employer agreements over pay and other conditions of employment. The reference point remains stand-alone firm-level bargaining as in the previous analyses. At the level of theory, Boeri argues that two-tier systems 
are inefficient because single-employer bargaining-as opposed to multi-employer bargaining under a right-to-manage mechanism-allows for efficient contracts involving both wages and employment. Since two-tier bargaining is construed as operating with a wage floor imposed by multi-employer bargaining, it reduces the scope of plant-level bargaining by shrinking the range of efficient contracts. On this view, then, no Pareto improvements are afforded by supplementary decentralized bargaining.

Now, in a setting of large productivity differentials across firms and regions, multiemployer bargaining by compressing nominal wage structures through conventional national agreements can lead to inefficient outcomes and distort incentives. Also, in taking industry bargaining as a wage floor, multi-level bargaining may amount to "paying twice" by setting a wage that can only be exceeded. But any consideration of how the two tiers might interact and how bargaining is articulated is suppressed in this treatment. Instead, the model rather assumes a structure that combines the "pay rigidity of centralized systems with the inattention to macroeconomic constraints of decentralized systems" (Boeri 2015, p. 1). ${ }^{15}$

There are just two justifications for two-tier bargaining in Boeri's schema. First, sectoral agreements could be retained for those firms where plant-level bargaining does not take place. Second, and more positively, there is scope for multi-employer agreements that set rules rather than wage changes to be applied uniformly to all firms irrespective of their performance. Somewhat reminiscent of some modern Scandinavian practice, the rules in question would govern the proportion of operational value added going to workers. He argues that these reforms would provide a (better) means of reconciling microeconomic flexibility with macroeconomic stability than two-tier bargaining per se. But to repeat, whether multi-level bargaining as currently practiced might be an intermediate step in this direction or whether it can be construed as pursuing decentralization consistent with single-employer bargaining while preserving degrees of freedom in macro adjustment is nowhere addressed.

It is entirely appropriate to subject collective bargaining structures to detailed theoretical and empirical scrutiny. And in the process, different structures may as we have seen evince compatibility. Nevertheless, against the backdrop of Visser's discussion, it may be argued that alternative bargaining structures have been accorded insufficient attention in recent theoretical models. One such potentially important characteristic is the synchronization of pay policies of distinct bargaining units or coordination. The final application considered in this section (re)introduces pattern bargaining as a means of coordination.

\subsection{The heterogeneity of bargainers}

Traxler and Brandl (2012) have considered the impact of bargaining structure on competitiveness viewed from the perspective of international trade/competitiveness and the importance of the heterogeneity of bargainers in their exposure to world markets. It is argued that the "competitiveness" of a bargaining structure depends on its ability to cope with intersectoral productivity differentials between the trading/exposed and non-trading/ sheltered sectors. The solution is said to require a non-egalitarian coordination of pay policies across the economy under the hegemony of the exposed sector (i.e., maintaining higher pay in the trading sector). 
How might different bargaining structures deal with the problem? The authors envisage three such structures: peak-level coordination, pattern bargaining (termed intermediate coordination), and uncoordinated systems. The core problem of peak-level coordination is uncertainty as to whether the redistributional compromise as set by the median affiliate holds, and this is said to depend on vertical coordination, namely whether the affiliates can bind lower levels (see Traxler et al. 2001). Accordingly, peaklevel coordination is characterized by either high governability or low governability. For its part, pattern bargaining with pattern setting by the exposed sector can theoretically fix percentage increases in pay below overall productivity growth while maintaining traditional differentials in favor of the trading sector. There results a moderate rate of increase in wages, where the pattern defines the ceiling for other settlements. Finally, since uncoordinated single-employer bargaining theoretically has the advantage of at all times achieving internalized pay settlements, there is supposedly neither the need nor the ability of the bargainers under perfect competition to respond to intersectoral heterogeneity. This advantage evaporates where there is imperfect competition in product markets, price setting power allowing externalized wage increases.

To evaluate the performance of the (four) different bargaining categories (state-imposed coordination serving as the reference category), the authors present a time-series cross section analysis of the determinants of the growth rate of nominal labor cost, the unemployment rate, and the current account balance for a sample of 18 countries, 1981-2002. In addition to bargaining structure, the other key RHS variable is differences in productivity growth between the trading and non-trading sectors. Beginning with nominal labor costs, it is found that peak-level coordination under low governability performs significantly worse than any other alternative. Although the other categories do not differ from the reference category of state-imposed coordination, the interaction term between pattern bargaining and intersectoral productivity differences is significantly negative, suggesting that the dampening effect of pattern bargaining on costs grows with widening productivity differentials. For its part, there is no effect of bargaining structure on unemployment. Finally, as far as the current balance is concerned, pattern bargaining (and peak-level bargaining with high governability) is associated with improved current balance. The bottom line of this empirical inquiry is that international competition rather than monetary signals influences the performance of bargaining and that exposed sector-led pattern bargaining offers the best fit to deregulated market internationalization, not bargaining decentralization per se. ${ }^{16}$ Note, however, one interesting result of this treatment: this model of coordinated pay policy while embracing international competitiveness "lacks comparative advantages in preserving employment" (Traxler and Brandl 2012, p. 94).

\subsection{Summary}

By way of summary, we began with a review of the empirical literature on bargaining structure and macroeconomic performance. This provided rather mixed results, especially after allowing for changes in institutions over time, but gave broad support to coordination mechanisms as a means of dealing with macro shocks, or at least in ameliorating the rougher edges of union impact. Since the empirical literature largely failed to incorporate a dominant characteristic of collective bargaining since the 
1990s, namely decentralization, we next focused on Visser's (2013) detailed and updated discussion of national collective bargaining institutions, documenting changes in bargaining coverage, the structure of bargaining, and bargaining coordination over time. His discussion of national systems contains a wealth of information on changing collective bargaining arrangements. Arguably, the diversity of practice within bargaining categories that is revealed is more instructive than the summary rank scores that are derived. In any event, this is one reason we have not commented upon, say, his final all-embracing centralization measure, or more directly sought to employ this or other of his parametric measures (e.g., coordination scores) in regression exercises analogous to those discussed at the beginning of this section. Rather, as far as empirical work is concerned, our preference has been instead wherever possible to identify findings from key studies of innovative practices associated with decentralization while investigating the impact of "supportive" extension ordinances.

Decentralization and coordination are the key issues for modern research into the design of fit-for-purpose collective bargaining institutions from the perspective of microeconomic and macroeconomic flexibility. The modern theoretical developments examined in this section generally applaud the decentralization of bargaining. Perhaps with an eye to coordination, they also recognize that sectoral bargaining with opt-outs and rule setting (rather than uniform wage changes) under multi-employer agreements can mimic the results of their decentralized bargaining models. That said, given the diversity of multi-employer bargaining revealed in Visser's pioneering treatment, insufficient attention has been given to sectoral bargaining and to coordination. We sought to illustrate this lacuna by reference to exposed sector-led pattern bargaining, which may also be seen as offering endorsement for the German model from another perspective. But this is not the only possibility, and research should turn to the different design features of sector-level bargaining systems that are more or less helpful in achieving micro and macro flexibility. Thus, for example, we alluded earlier to the modern Scandinavian model by which we meant industry agreements that allow a significant amount of pay to be performance related and that function as defaults while gaining centralizing traction from mediation procedures.

Two final considerations are, firstly, the general failure of the modern literature to address the endogeneity of collective bargaining (for an exception, see Boeri and Burda 2009) and, relatedly, the sparse consideration accorded wage moderation under decentralization vis-à-vis individual wage negotiations. In the latter context, and on the basis of German data, Ochel (2005) concludes that there is no indication that the growth of company-level collective agreements has led to more moderate settlements. He also argues that agreements based on contractual opt-out clauses have not resulted in more moderate wage contracts than at the branch level while achieving wage flexibility. However, as we have seen, it is all too easy to miss the wage cuts that result from the application as opposed to the existence of opening clauses and the nature of the insurance function. Moreover, research by Garloff and Guertzgen (2012) suggests that flexibility provisions under sectoral agreements do affect the sensitivity of wages to local firm conditions once account is taken of more poorly performing firms. The latter study also reminds us that rising wages are not destructive of the decentralization argument, a result that is underscored by emerging evidence on favorable productivity development under successor pacts. 


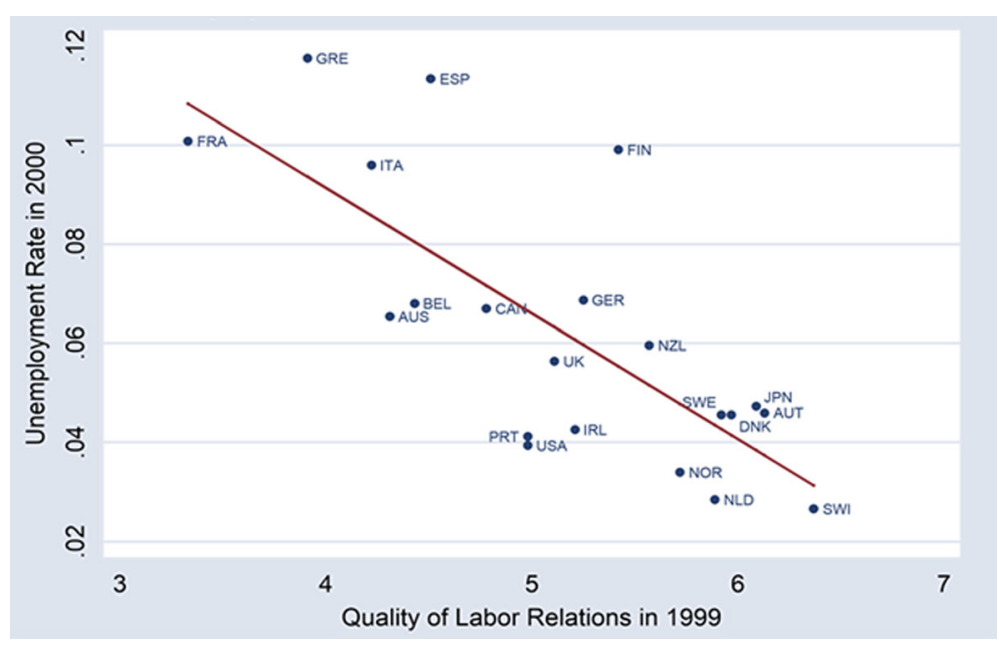

Fig. 1 Unemployment rate and labor relations in 21 OECD countries

\section{The neglected issue of trust}

In an important qualifying comment on the implications of alternative collective bargaining institutions for macro flexibility, it has recently been argued by Blanchard et al. (2013, p. 20) that "trust among the social partners appears to be just as important in bringing about macro flexibility as the structure of collective bargaining." Trust may of course be no less important in achieving micro flexibility, and we have already commented on the potential of collective voice to improve the functioning of internal labor markets and generate productivity growth. It will be recalled that the value-enhancing role of (union) collective voice hinges crucially in the model upon a constructive institutional response from management and a cooperative industrial relations environment. We also noted that analyses of strikes have offered some interesting insights into the quality of industrial relations at the workplace and the effect of the latter on productivity and on output quality. We now turn to consider trust more directly. First, at a more general level, we consider the association between trust and unemployment, together with some research findings on the relation between trust and the design and quantity of labor market legislation. Second, and more connected to our prior analysis, we examine whether trust has diminished as a result of the "turmoil" in wage-setting institutions diagnosed by Visser (2013) and address social pacts that may either be viewed as requiring trust or as substituting for it. There are intriguing indications of trust considerations helping shape labor market institutions and influencing economic outcomes.

\subsection{Trust and unemployment}

As far as macro outcomes are concerned, simple correlations linking trust and unemployment point to strong negative cross-country associations. Figure 1 presents one such archetypal relation between trust and macro performance for a sample of 21 OECD countries. The indicator of trust is that reported in the 1999 Global Competitiveness Report, published by the World Economic Forum (WEF), and the outcome 
indicator is the corresponding unemployment rate in 2000. The measure of trust was derived from the answers of senior executives to the following question in the WEF survey: "Labor/employee relations are generally cooperative." Responses can vary from 1 (strong disagreement) to 7 (strong agreement) and where actual mean responses varied from 6.4 for Switzerland to 3.3 for France. The $R^{2}$ for this linear relationship is 0.55 . An increase in trust from 3.3 to 6.4 is associated with a decrease in unemployment of 7.7 percentage points (Blanchard and Phillipon 2006, p.3).

The key question is of course whether the association remains significant when other labor market institutions are included. Blanchard and Phillipon (2004) have concluded that this in indeed the case in a multi-variate analysis of labor relations and unemployment, 1979-2002. Their basic argument is that in countries where wages are largely determined by collective bargaining, the effect on unemployment of changes in the economic environment will depend in large part on the speed of learning of unions. The latter is seen as a reflection of the quality of the dialog between the two sides or the quality of industrial relations. Taking a cue from the US micro literature, Blanchard and Phillipon proxy industrial relations quality by strike intensity averaged over 1960-1967.

The authors first present simple regressions of unemployment in each of the four decades (1965-1974, 1975-1984, 1985-1994, and 1995-2003) on the strikes measure and then on a second direct measure based on the perceptions of business executives of the quality of industrial relations, as reported in the WEF survey mentioned earlier. Since the outcome measure might be reflected in the responses, Blanchard and Phillipon ultimately use the 1960-1967 strike data to provide a predicted value for the 1999 survey measure. (See also Blanchard and Phillipon 2006, who use historical evidence on the attitude of the State toward early unions in the nineteenth century to construct an instrument for labor relations in 1999.) The simple regressions indicate a strong and statistically significant effect of the quality of industrial relations (all three measures) on unemployment.

The authors' preferred specification interacts the instrumented measure of the quality of industrial relations with unobservable shocks common to all 18 OECD countries in their sample. In fact, this indicator of cooperation is but one of nine institutional variables in the model (including coordination of bargaining), so that the impact of a common shock depends on a linear combination of all nine institutional arguments. Strikes remain positively related to unemployment, and although the point estimate declines somewhat in magnitude, it is still highly significant when the other eight regressors are added to the equation. The bottom line of this inquiry is therefore that countries with inferior labor relations/lower trust have paid a stiff price in terms of elevated joblessness and that the beneficial quality effect is additional to any structural benefits provided by union and employer coordination in collective bargaining.

Addison and Teixeira (2009) attempted to replicate the above model in an approach incorporating a number of innovations such as the use of time-varying institutional variables (including the strike measure). Support for the notion that macro performance owes something to good industrial relations found in pooled OLS estimates no longer holds when the authors control for country effects in their baseline model and add country dummies to the non-linear version of the model. Similarly, use of a first-pass 
procedure designed to control for the endogeneity of strikes fails to resurrect the Blanchard-Phillipon result. That said, these conclusions are necessarily tentative because of potentially serious measurement error in the strike variable. Accordingly, this is emphatically not the last word on trust and unemployment.

\subsection{Trust and labor laws}

Recent work on trust has focused on the role of civic attitudes (highly related to trust) in explaining labor market institutions and the relation between state regulation of labor markets and the quality of industrial relations. On the former question, Algan and Cahuc (2009) have examined the balance between two related labor market institutions designed to offer protection from job loss, namely unemployment insurance benefits and job protection legislation in a sample of OECD countries, 1980-2003. They report that countries displaying high civic values-proxied by answers to the question do you think it can always be justified, never be justified, or something in between to claim government/state/benefits to which you have no right?-tend to insure their workers through unemployment benefits instead of using stringent employment protection. That this relation is a causal is suggested by a unique epidemiological approach using the inherited part of civic attitudes as an instrument for civic attitudes in the home country. Vulgo: moral hazard-the product of un-civic attitudes-influences the implementation of efficient labor market institutions.

On the latter question concerning state regulation and the quality of industrial relations, Aghion et al. (2009) exploit the negative association between state regulation of minimum wages and the quality of industrial relations (the latter again based on the World Competitiveness Report data). The authors contend that this relation will reflect different ways of regulating labor markets-either through the state or through civil society (i.e., unionism), depending on the degree of cooperation in the economy. On the authors' model, distrustful labor relations lead to low unionization and a high demand for state regulation of wages. Once in place, strong state regulation crowds out the possibility for workers to engage in negotiation and learn about the potentially cooperative nature of labor relations. As a result, there can be multiple equilibria, with a bad equilibrium characterized by poor, uncooperative industrial relations and extensive state regulation of the minimum wage and a good equilibrium in which labor relations are cooperative as indexed by high union density and low state regulation.

\subsection{Trust and the pace of change}

Has the pace of institutional change-charted by Visser $(2013,2016)$ in particular-impaired trust and with it the efficacy of collective bargaining as reflected in economic performance? A very recent study by (Brandl and Ibsen: The effects of institutional instability in collective bargaining: a long-term analysis of changing collective bargaining actors and structures, Unpublished) offers a preliminary investigation of this issue. The basic idea is that institutional stability fosters trust between organized labor and capital by creating mutual expectations about behavior that underpin stable wage determination and the provision of the public goods of wage moderation. For its part, change implies collective action problems and an increase in transaction costs of a short-tomedium term ( 2 to 4 years) nature. The hypotheses are tested with annual data from 1965 
to 2010 for 33 countries using time-series cross section methods. The dependent variables are twofold: inflation and the unemployment rate. The key RHS variable, institutional instability, is based on changes in the structure of the coordination of collective bargaining. Five such categories are identified: company-wide/uncoordinated bargaining, companywide/weakly coordinated bargaining, industry-wide/weakly coordinated bargaining, industry-wide/coordinated bargaining, and economy-wide bargaining. The "magnitude" of change is not measured, and in the first instance, neither is the direction of change. However, the frequency of changes is captured. It is assumed that negative effect on trust weakens through time; operationally, the time taken to restore trust is set at 1,2 , or 4 years. Controls include economic, collective bargaining, and industrial relations variables.

It is reported that the more frequently the institutional structure of collective bargaining is changed, the more pronounced is unemployment and the higher is inflation, from which result the authors contend that there are no net benefits of new institutional structures for up to 4 years after the transition. The contribution of the five collective bargaining and industrial relations controls is both modest and limited to the unemployment outcome-more coordinated bargaining being associated with lower unemployment and higher union density with greater unemployment. Distinguishing between the direction of change in the structure of coordination does not change the results qualitatively; that is, both directional movements are associated with elevated unemployment and higher inflation. ${ }^{17}$

\subsection{Trust and social pacts}

A separate literature that may be viewed as incorporating trust, or lack thereof, has focused on social pacts, namely macro-level tripartite arrangements that are designed to improve economic performance through wage moderation, to synchronize bargaining with economic policy so that the macro goals of competitiveness and price stability can be met. Social pacts have been negotiated in a number of European countries. Their use has been frequent in Finland and Ireland where they have taken the form of taxbased income policies and also but rather differently in the Netherlands and Italy. In the Netherlands, pacts have been instruments to adjust expectations downward and moderate wage demands in times of crisis, the 1982 Wassenaar Agreement being the classic example; in Italy (and also in Spain), pacts have established framework rules for industry and company bargaining.

Whatever the achievements of pacts in facilitating a favorable adjustment of prices and wages in the face of major economic shocks, and in securing improvements in labor markets in difficult circumstances, they are intrinsically fragile instruments in their coordination. In this regard, it is commonplace to allude to the collapse of social partnership in Ireland in 2009 and to the withdrawal of Fiat from the employers' confederation Confindustria in 2012. Social pacts are necessarily contingent institutions that, even where accompanied by supportive networks, and systems of mutual commitment and obligation, are difficult to negotiate and stabilize (see Avdagic et al. 2011).

One strand of the analysis of pacts has seen their success as reflecting mutual trust among the economic actors and their failure as indicating an absence of trust. The remarkable improvement in the Dutch economy post 1982 has been linked to that 
nation's culture of a search for consensus in combination with a far-reaching institutional consultation structure that has produced an environment of mutual trust and cooperation. By the same token, the abortive negotiations in Greece and Portugal during the most recent economic crisis have been linked (albeit less formally) to a lack of trust between the government and the social partners.

The Dutch case has been the subject of more detailed scrutiny. In particular, Den Butter and Mosch (2003) discuss the manner in which the Dutch (or polder) model has been able to produce interpersonal and inter-organizational trust and how that trust resulted in sound economic policies. In the former context, having addressed the social characteristic of the drive for consensus in that nation, the authors identify the major players involved in policy, chiefly the advisory Central Planning Bureau, and the consultative bodies of the bilateral Foundation of Labor and the tripartite Social Economic Council. The workings of the economy are described by the independent Central Planning Board's economic models, and the balancing of the different points of view is arranged by the government in dialog with unions, employer organizations, and other organized interests. Deliberations of the employers and unions in the Foundation of Labor on labor standards are manifested in the so-called central agreements. For its part, the Social Economic Council serves as the main policy advisory board for the government on social and economic matters. Interestingly, although the government freed itself of the obligation to consult this body on all socioeconomic matters in 1995, the result was to stimulate consensus building such that the Council now issues unanimous if non-binding policy recommendations to the government. The negotiators in the Council meet regularly, both formally and informally.

In discussing wage negotiations at the central, industry, and micro levels, Den Butter and Mosch pay especial attention to the specific incentives offered to the parties to cooperate and reach agreement. In the process, it is argued that the Dutch institutional framework closely conforms with micro arguments on how to build trust-enhancing networks. In examining the specific micro conditions of Dutch policy and the manner in which trust contributes to economic growth, the authors anchor their analysis in the hold-up problem that characterizes the wage-setting process. The solution to the problem of opportunism that arises is to assign the right to adjust contracts to a higher level, negotiators at this level being less prone to opportunism.

This leads to the final component of the analysis, namely how trust translates into sound economic policies. Here, the practicalities are those of the Wassenaar agreement reached in the Foundation of Labor. Between 1982 and 2000, unemployment fell from a high of $14 \%$ to a low of $2.5 \%$, labor participation rose from $52 \%$ to the European average of $65 \%$, and government finances moved into surplus from an $8.5 \%$ deficit. As noted above, this agreement linked wage moderation to a reduction in working hours. It was non-binding and therefore a point for negotiations about labor standards at lower levels. But it changed the outcomes of negotiations at industry and firm levels and was indeed to be followed by a series of further central agreements. Stimulus was provided by the economic model of the Central Planning Bureau that pointed to strong employment growth from lower labor costs. The agreement also marked a retreat of government from labor market negotiations, although it was to support Wassenaar by reducing taxes and social security premiums. Currently, the government leans on the bargaining table at times of economic downturn in an attempt to garner support for 
wage moderation. And today, as in the past, there are instances of government support for wage moderation; for example, in 2009/2010, it helped finance temporary shorttime working on the German pattern. But the direct intervention that characterized its activity in the years before 1982 is a thing of the past. ${ }^{18}$

Another strand of the literature on social pacts has focused on the shift in their nature. According to Hassel (2003, p. 722), the social pacts of the 1980s and 1990s are to be distinguished from the neo-corporatist policies of the 1970s that involved a political exchange of wage restraint for policy concessions, the new pacts being instead interactions between government and unions in which governments set new tighter conditions for wage bargaining. On this view, pacts might at a pinch be depicted as a substitute for trust, not least given their occurrence in some "unlikely countries."

Taken as a whole, these results of incorporating trust "into the equation" are to be welcomed. Although there are many unsettled issues (e.g., causation), there are distinct indications that trust may shape labor market institutions and influence economic outcomes. One pressing research concern, however, is identification of the design features of collective bargaining that help build trust.

\section{Earnings dispersion}

If the simple associations between institutional regimes and macroeconomic performance demonstrate fragility over time, there is one striking exception: the negative association between unionism and earnings dispersion, whether we are speaking of union density, coverage, or bargaining structure/coordination (see, inter al., Flanagan 2003). Equivalently, union decline is allied to rising inequality. We will examine the historical evidence in more detail below, but first, we examine the relevance of inequality to macroeconomic outcomes. Here, one of the factors considered in the preceding section as potentially important in bringing about macroeconomic flexibility-trust-may itself be an inverse function of inequality.

\subsection{Inequality and macro outcomes}

According to Dabla-Norris et al. (2015), the prime reason for concern over rising inequality is that income distribution matters for growth. Using a model in which GDP growth is regressed on initial income, lagged GDP growth, and inequality as proxied by the net Gini coefficient (i.e., net of transfers and taxes) or by the income shares of the five income quantiles for a sample of 159 countries, 1980-2012, and controlling for time and country fixed effects, the authors find a strong negative association between the inequality measures and growth. Specifically, if the income share of the top (bottom) quintile increases by 1 percentage point, GDP growth declines (rises) by 0.08 (0.38) percentage points. (The equation is estimated using system-generalized method of moments, whose procedure tackles endogeneity problems with RHS variables, while the time and country fixed effects control for common shocks and time-invariant country-specific effects.) The coefficient estimates for the second and third quintiles are also positive. Observe that the reported negative implications of rising inequality for growth are not unique to this study (see, for example, Berg et al. 2012; OECD 2014).

What are the mechanisms underpinning this inverse relation between inequality and growth? They are said to be fourfold. First, greater inequality impacts investments in 
health and human capital, with knock-on intergenerational effects. Second, inequality harms short- and long-term growth through a causal effect on crises. This instability may also come about by damaging trust and social cohesion. Third, rising inequality can frustrate economic liberalization. Fourth, inequality makes it more difficult to reduce poverty via growth.

Dabla-Norris et al. model the determinants of the Gini coefficients (net and market) and income shares (top and bottom income deciles as well as the fifth decile) using 5year panels of data for 1980-2012. In addition to trade, technology, health, government spending, financial arguments, and the skill premium, the authors also deploy a decline in labor market institutions or rising flexibility index. An easing of labor market regulations is reported to be associated with rising market inequality and is accompanied by rising (falling) share of top (bottom) income deciles. But since (refined) labor variables are the focus of more detailed inquiry in Jaumotte and Osorio-Buitron (2015), we remit further discussion of this result till later.

\subsection{Unions and inequality}

Detailed country studies have basically confirmed the result that unions narrow earnings dispersion and that union decline has led to increases in inequality even if, as we shall see, such results are subject to qualification. The union effect on the wage distribution arises from two distinct effects. The within-sector effect is negative because of wage standardization between within and across firms and the tendency for unions to reduce the wage gap between blue-collar and more highly paid white-collar groups. The between-sector effect widens inequality via the union wage premium. Early work by Freeman (1993) for the USA established-quite contrary to prior orthodoxy-that unions narrowed the male wage distribution and declining unionization widened it significantly between 1978 and 1988. Since then, improved studies using reweighting approaches to recover the counterfactual wage distribution that would have obtained had the workforce composition remained unchanged (see DiNardo et al. 1996) have examined the union wage effect across different types of worker and sought to control for unobserved skill differences (that contribute toward a compression in worker skills in the union sector).

Comparative second-generation studies of this type have been conducted by Card et al. (2003, 2004). The authors investigate unions and wage inequality in the USA, the UK, and Canada-countries in which there is perhaps the clearest distinction between the union and non-union sectors-since the early 1980s. Their main findings are as follows. First, unions tend to reduce inequality in all three countries among male workers for whom the within-sector effect dominates the between-sector effect. Second, controlling for worker quality reduces both effects, as union workers are more skilled on average and more homogeneous than non-union workers. Third, union coverage tends to be concentrated in the middle of the male skill distribution and union wages tend to be compressed vis-à-vis non-union wages. Fourth, for this sample, unions do not reduce wage inequality among females because (a) women unlike men are concentrated in the upper end of the wage distribution and (b) the union wage premium is not only greater for women but also greater for higher-skilled women. Finally, the decline in density and the wage differential observed for all three countries has resulted in a steady decline in the equalizing effect of unions. 
If the size of the union sector and absence of extension mechanisms in these three countries make it easier to compare the structure of wages for workers whose wages are determined by union contracts and those whose wages are not, other-country studies have nevertheless confirmed the same basic tendencies. Thus, evidence for Germany also indicates that part of the increase in inequality can be attributed to declining unionization. Dustmann et al. (2009), building on micro studies indicating strong evidence that unions compress the wage structure and particularly at the lower end of the wage distribution (e.g., Fitzenberger et al. 2013), report that the decline in union recognition between 1995 and 2005 had a material, if not dominant, effect on the wage structure. Specifically, they find that deunionization can account for $28 \%$ of the increase in the 50-15 percentile wage gap and $13 \%$ in the $85-50$ percentile gap. In other words, the effect of union decline was felt most at lower reaches of the wage distribution.

More recent research by Dustmann et al. (2014) links rising inequality to the decentralization of collective bargaining and not simply to the decline in unionization (but see below). Specifically, the authors examine wage growth by the 15th, 50th, and 85th percentiles of the wage distribution. It is found that wage inequality in the covered sector grew at the bottom and at the top of the wage distribution (whereas in the uncovered sector, it was confined to the top of the wage distribution). The change in wage inequality in the covered sector is loosely attributed to decentralized wage setting and in particular to the growth in opening clauses after 1995. The argument is prima facie consistent with other research pointing to the increasing role of firm-level differences in wages as a source of rising German wage inequality (e.g., Card et al. 2013).

The most recent attempt to investigate the effect of unionism (and other labor market institutions) on income inequality is that of Jaumotte and Osorio-Buitron (2015), who look at the experience of some 20 advanced economies from the early 1980s to 2010. Their event study and panel regression analyses suggest that the decline in union density is related to the rise of income inequality at the top of the income distribution. This not uncontroversial result is conjectured to reflect an implicit increase in the bargaining power of top earners with the reduction in that of average wage earners and also a more limited worker influence on redistributive policies.

Focusing here on the authors' panel regression analysis, Jaumotte and Osorio-Buitron first regress two measures of gross income inequality (namely the top $10 \%$ income share and the Gini coefficient of gross income) on labor market institutions. The controls in addition to country and time fixed effects comprise technology, globalization, an index of financial reform, the top marginal tax rate, and a banking crisis variable. The labor market institutions are union density, excess collective bargaining coverage (viz. coverage less density), the value of the minimum wage in relation to the median wage, the first-year gross unemployment benefit replacement rate, and a measure of the employment protection afforded regular and temporary employment contracts. A separate regression analysis of the Gini coefficient of net income inequality is also provided in which a key RHS variable is the Gini coefficient of gross income, the other arguments being a subset of those considered earlier. In each case, a benchmark equation is run containing all the controls plus union density (and the minimum wage). Next, the estimating equation is augmented by an excess collective bargaining coverage variable. Finally, the rest of the labor market arguments are added (and excess collective bargaining coverage dropped). 
For gross inequality, it is found that a weakening of unions is associated with an increase in the top $10 \%$ income share, while its association with the Gini coefficient of gross income is also negative. Specifically, in the baseline equation, a $10 \%$ decline in union density is associated with a $5 \%$ increase in the top $10 \%$ income share. Interestingly, in the first augmentation, excess bargaining coverage is positively associated with inequality while the union density coefficient estimate is basically unchanged. Finally, the impact of density is also unaffected by the inclusion of the other labor market institutions, the role of which is not commented upon here.

As for the determinants of redistribution, apart from the result that the coefficient estimate of the Gini of gross income is less than unity, which indicates the impact of redistribution, the role of union density is again negative and well determined. The suggestion is, then, that unions influence redistribution whose role has therefore been reduced in the wake of their decline.

Given the rather surprising results of this study-after all, the orthodox view is that changes in unionism affect middle- and lower-income workers-Jaumotte and Osorio-Buitron embark on an exhaustive series of robustness checks. These include controlling for sectoral shifts/deindustrialization, skill-biased technical change, social preferences in favor of greater inequality, the role of the finance sector, rising levels of formal schooling, and even the endogeneity of the union variable. ${ }^{19}$ In each case, the union argument proved robust, actually increasing in absolute magnitude vis-à-vis the benchmark equation. Interestingly, the authors also regressed union density on separate (net) income decile shares, using the same controls as the baseline equation, yielding familiar results for the lower ranges of the income distribution. That is to say, the union density coefficient estimates were positive for the bottom seven deciles indicating the familiar result that union decline harms a wide swathe of middle- and lower-income earners. But, as before, the density coefficient estimate in the case of the top decile was negative; it was also considerably larger in absolute magnitude.

Now, all such results are subject to qualification. For example, in charting the effects of the decline in British unionism between 1983 and 1995, Addison et al. (2007) report that deunionization accounts for surprisingly little (under $5 \%$ ) of the increase in earnings dispersion in the private sector for both males and females. In both cases, standardization effects largely offset a decline in density and a shift in membership toward the more-skilled. In the public sector, however, there has also occurred a profound shift in organization toward more-skilled workers, especially among females. This meant that a much smaller decline in unionization accounted for between 30 and $40 \%$ of the increase in dispersion, whose effect is of course more properly to be construed as "re-unionization."

The theme that unions have come to organize better-paid workers is taken up in the final study considered here. Pontusson (2013) examines the association between unionization, inequality, and redistributive government policies in a sample of OECD countries from 1975 to the present. Over the interval 1975-1995, Pontusson observes that countries that witnessed relatively large declines in unionization also experienced relatively large increases in earnings inequality, as measured by changes in the 90:10 earnings ratio. Since 1995, however, no such association is evident in the data. He then examines the link between changes in redistribution (measured by the percentage 
change in the Gini coefficient produced by taxation and income transfers) and changes in union density. A regression of the change in redistribution on the change in union density-controlling for the initial level of redistribution, or catch up, and inequalityinduced redistribution captured by the change in the Gini coefficient for market income-yields a positive and statistically significant effect of unionism for the sample period 1980-1995. Over this interval, increasing unionism thus seems to have exerted pressure on governments to redistribute and conversely. For the period 1995-2010, however, the coefficient estimate for the change in union density is negative and statistically insignificant, suggesting that changes in union density were no longer linked to redistribution.

Pontusson thus argues that the egalitarian effects of unionization-for governmentled redistribution and the distribution of earnings from employment-have diminished over the past two decades. By way of explanation, he finds that the material decline in union density in many OECD nations since the 1970s has been accompanied by important changes in the position of union members in household income distribution. In a clear majority of OECD countries examined, union density peaks in either the fourth or fifth quintiles. Pontusson's conclusion that the average union member has become better off as union density has declined and that union members have become less supportive of wage solidarity and redistributive policies is suggestive rather than definitive, but it provides an interesting point of contact with Jaumotte and Osorio-Buitron who, in support of their findings as to the impact of deunionization on top income shares, might argue that this in part resulted from weak unions having lost their voice in the public policy debate on redistributive policies as well as on policies that affect market income inequality.

There are at least three remaining issues. The first is the question of how equalizing is equalizing. The second is the related issue of the efficiency of equalization. The third is the vexed question of decentralization versus deunionization. First of all, crosscountry data from the 1970s to the 1990s on collective bargaining coverage, earnings inequality, and unemployment assembled by Pencavel (2005, pp. 71-74) suggests that unions in continental Europe may have helped to prevent wage inequality albeit largely at the expense of greater unemployment (see also Boeri 2015). His explanation is that unions have improved the wage position of the lower- to middle-skilled groups that have been most impacted by the shift toward more competitive product markets produced by heightened trade, increased factor mobility, and technological change. However, as a referee reminds us, this is an over generalization in that it fails to recognize that unions in a number of countries-examples would include Austria, the Netherlands, and Denmark-have actively sought to reverse wage policies that have had this effect.

Second of all, pay compression can have positive and negative effects on efficiency. The case is nicely illustrated by Flanagan (2003, p. 182) who distinguishes between two types of equal pay pursued historically under the old solidaristic wage policies of Swedish unions. One such policy was "equal pay for equal work" practiced in the mid-1950s, and the other was "equal pay for unequal work" that followed in the late 1960s. Flanagan shows that a policy eliminating inter-establishment and inter-industry wage differentials can raise productivity growth by accelerating job destruction in relatively inefficient (older) plants and by stimulating job creation in new, more- 
efficient plants. On the other hand, equal pay for unequal work detracts from productivity growth, for example, by reducing the incentives to acquire human capital.

Third of all, even if deunionization leading to individual bargaining of employers with their employees may be regarded as the ultimate form of decentralization, it is clearly not what is meant by the decentralization of collective bargaining, although the two are linked under disorganized decentralization based an erosion of multi-employer bargaining. We know of no real attempt to unpick the component magnitudes. Most of the research on inequality has simply focused on the decline in union density or coverage. Perhaps the main exception is the diagnosis of widening income inequality in Germany by Dustmann et al. (2014), briefly reviewed earlier, in which earnings dispersion within the covered sector is examined alongside that of the uncovered sector and not simply linked to declining overall density. These authors attribute the dramatic turnaround in German competitiveness to unit cost reduction made possible by deunionization on the one hand and by the decentralization of collective bargaining (opening clauses) on the other. As a result, so the argument runs, German unemployment barely budged during the Great Recession, reflecting the specific governance structure of German labor market institutions that enabled them to react flexibly in a time of extraordinary economic circumstances. But the authors do not identify the contribution of decentralization.

\section{A caveat: collective bargaining systems and other institutions}

This review has neglected the interplay between collective bargaining systems and other labor market institutions, other than having made reference to the elevated unemployment effect of the tax wedge in countries with liberal extension procedures and other such interactions in the distinct strikes literature. However, as the OECD (2004, p. 165) has observed, "the impact of the organization of collective bargaining on labor market performance appears to be contingent upon other institutional or policy factors and these interactions need to be clarified to provide robust policy advice." And indeed, in estimating unemployment equations inter al., the pre-crisis macro literature did allow for interactions between collective bargaining and other labor market institutions. Clearly in assessing the effects of the new institutional developments charted here-of which the most important is decentralization, this interplay needs to be modeled. Thus, for example, in the presence of multiple objectives (e.g., efficiency and equity), decentralization may offer efficiency gains at the expense of equity. In such circumstances, it makes sense to consider other tools to mitigate or confront the problem. Again, experience might suggest that other well-designed institutions may facilitate the political economy of reforms to the collective bargaining system. Thus, flexicurity programs on the Danish pattern might help alleviate worker concerns over more flexible wage-setting systems. In considering the design of an appropriate collective bargaining system, then, the limitations of our focus upon any single "tool" has to be kept in mind. But first, the changes in collective bargaining documented here await formal expression in macro models.

\section{Conclusions}

Although one has to be especially careful when discussing existing structures of collective bargaining by reason of their manifest diversity and continuing evolution, the trend 
toward decentralization, although not outright convergence, seems incontrovertible. The economic reasons for that decentralization also seem uncontroversial. The evidence suggests that what is needed for efficiency is a collective bargaining system that allows for local adjustment while retaining coordination to facilitate macroeconomic adjustment. This requirement covers a multitude of sins of course since there are numerous forms of adjustment to local circumstances and coordination. One option is the new Scandinavian model of industry bargaining with articulation, where local bargaining controls much more of overall earnings that are increasingly determined by performance and which contain an individualized component. Another option is sectoral bargaining at the branch level accompanied by works agreements on the German pattern (i.e., between management and works councils). These would presumably involve the application of opt-out clauses that might be expected over time to morph into pacts for employment and competitiveness. Integrative bargaining at the local level is ultimately the key. The German system in principle allows works agreements to focus upon issues of production rather than distribution and may be more appealing theoretically. It may also be viewed as more exportable than the Scandinavian model for sectoral bargaining systems with weak unions. It may even be more appealing given contemporary (Swedish) unemployment rates. The latter might also serve to refocus attention on the Anglo-Saxon model from the perspective of micro and macro flexibility, since there is the suggestion that micro flexibility in the UK has arguably facilitated macro flexibility (but see below).

We have also suggested that trust among the social partners may be just as important as structures in bringing about macro flexibility in making a case for the polder model. Trust at the micro level is no less important, and it may also have a bearing on the performance of models. Two examples are instructive here. First, Marsden (2015) has contrasted work systems in Britain and Germany. He contends that although British employers have re-established control over the work process in manufacturing, after the dark days of the 1960s to the 1980s, they have (often) done so by ensuring that workers remain easily substitutable so that the dismissal threat remains credible. There results a hierarchical model relying on managerial control and a so-called lean model of work organization. By contrast, the German dual system uses high-performance work systems that involve flexible working and on-the-job problem-solving, maintaining high degrees of worker autonomy in a learning model of work organization (recall Exhibit 1). German firms in consequence have not had to sacrifice skill assets through narrow jobs and restricted worker flexibility and knowledge. The learning model has been facilitated by separating wagesetting responsibility from that for workplace issues under the dual system. As a result, line managers have not been able to use pay as a resource to get employees to accept line assignments, while for their part, individual workers and work groups could not make their acceptance conditional on doing a deal with their manager. Marsden argues that, by dividing areas of employee influence in this way, the German system has been able to provide sufficient voice to sustain cooperation while making it harder to use strength in one area to support demands in another.

A second example is provided by Nienhueser and Hossfeld's (2011) case study which examines the trust between works councilors and managers in Germany and how this affects their preferences for plant-level negotiations as compared with industry-wide or multi-employer bargaining. Nienhueser and Hossfeld anticipated that mutual trust 
would be manifested in both parties having a preference for plant bargaining. Their descriptive analysis duly confirmed the very high degree of trust in the respective bargaining partners. However, the authors' regression analysis produced no evidence that trust affected management's already strong preferences for decentralized bargaining. For works councilors whose preferences for decentralized bargaining were very much lower than those of management to begin with, it was found that low trust strongly reinforced that less favorable view of decentralization.

It follows that the role of trust and its interaction with the institutions of collective bargaining needs to be accorded greater attention in research. Focusing here on a line of causation running from collective bargaining to trust, the design features of collective bargaining systems that could potentially help build up trust would include built-in incentives to continue bargaining rather than walking away in the case of failure, government involvement, and long-term contracting. On this basis, we would (also) adduce support for the polder or Dutch model.

We have also had occasion to examine extension agreements that support sectoral bargaining by making it less risky for employers to sign such agreements. Whatever the usefulness of extensions in this regard, our discussion has suggested that the cost of automatic extension may be severe. Allowing firms in difficulty to opt out and exempting the long-term unemployed would be obvious temporary palliatives. Carefully refining thresholds to ensure that the bargaining parties represent a majority of employers and employees in the industry would be a more thorough-going means of reducing the costs of these ordinances. One nagging issue that remains, however, is the role of ordinances in stimulating the informal sector.

Some final issues are associated with deunionization. The first is the impact of union decline on wage and income inequality. Causality (in the absence of fully fledged general equilibrium analysis, inter al.) is arguably less of an issue here than the magnitude of the union effect. Measurement is important not least because a recent research literature has provided concrete evidence that increases in inequality retard growth. In any event, extant findings do not admit of obvious policy solutions in the form of more unionization or higher minimum wages. Thus, the gamut of (adverse) welfare consequences of union actions in times of stronger unionism has to be considered while minimum wages can harm low-skill groups and result in a loss in competitiveness. And although the inequality issue is unlikely to go away, other determinants of risingnequality may be more important as well as more tractable components of any reform agenda. There is also the issue of the role of decentralization in this regard. Arguably, disorganized decentralization is the link. That said, even organized decentralization may coexist with a shrinking core, with not dissimilar implications for the wage distribution.

But might it not be claimed that declining unionism has caused an unambiguous shortfall in worker voice, the provision of we have argued to be critical for microeconomic flexibility? If a prima facie case does exist for measures supportive of voice, the downside is the growth in bargaining power attendant upon measures favoring increased worker representation. The bargaining problem means that employers can be expected to vest voice institutions with too little power. This returns us to the appeal of the German model and method of workplace representation because of the practical limits placed on rent seeking by the works council, including a peace obligation. 
Indeed, we earlier conjectured that a German-like system may allow a decoupling of the factors that determine the size of the joint surplus of an establishment from the factors that determine its distribution.

As a practical matter, there are indications that outside the USA where the Wagner Act has undoubtedly had a chilling influence and may well require reform, ${ }^{20}$ non-union voice has increased. For example, the most recent research for Britain finds that the decline in union voice has been accompanied by a dramatic expansion in non-union voice, such that the overall coverage of voice mechanisms has remained high and stable (Bryson et al. 2013). Thus, British employers have seemingly chosen non-union voice rather than opt for no voice at all. Moreover, comparing voice regimes, non-union voice is reported to have outperformed union voice for a variety of subjectively defined measures (industrial relations climate, productivity, and financial performance-if not quits), while there is also greater use of human resource management practices under non-union voice. These results give credence to the notion that management has had an incentive to invest in non-union voice, although this conclusion is subject to interpretation partly because of the joint use of both channels. Unsurprisingly, therefore, the efficacy of non-union versus union voice remains the subject of continuing debate.

\section{Endnotes}

${ }^{1}$ To gage whether these results might instead be picking up cross-country (as opposed to firm-specific results), the probit regressions are rerun for separate samples of countries according to whether their collective agreement coverage is high or low. It is found that, with the exception of the coverage variable, the results reported above reflect within-country rather than cross-country differences.

${ }^{2}$ More broadly based cooperation also receives emphasis in the new view of unions. That is, Freeman and Medoff emphasize the importance of the quality of labor relations. They state explicitly that good labor relations are more likely to produce positive performance outcomes, whereas highly antagonistic relationships or forms of bad labor relations can lead to adverse performance effects. Formally last in the Freeman-Medoff scheme of things is the shock administered by unions, and union wages, to inefficient management, providing it with the incentive to tighten up on work standards and alter methods of production.

${ }^{3}$ While DiNardo and Lee also report that unionism has no effect on hours of work, a recent study of nursing homes by Sojourner et al. (2012), using the same regression discontinuity design, finds that hours of work, as a proxy for employment, decline precipitously as a result of union certification in representation elections.

${ }^{4}$ Although a more recent study by Bryson et al. (2011) concludes that British unions still do depress firm profitability where there is active collective bargaining. This study also reports not dissimilar results for France if union density is high or where unions have a reputation for militancy.

${ }^{5}$ While the decline in British union density over this period may be ascribed in part to globalization, the UK is unique in that six major pieces of legislation designed to address union power were introduced by successive conservative administrations between 1980 and 1993 (see Addison and Siebert 2003). These reforms were accompanied by the abolition of exchange controls, the dismantling of statutory wage-fixing machinery, a sustained program of privatization of the nationalized (and notably heavily unionized 
industries), and deregulation. There can be no doubt that the union reforms independently hit union density (e.g., Freeman and Pelletier 1990) and also little disagreement that they lie behind the changes in the micro performance outcomes noted earlier.

${ }^{6}$ This linear relation between performance and the degree of centralization is often loosely referred to as the corporatist thesis. Given that corporatism incorporates the effects of the political environment on the macroeconomic effects of collective bargaining, and given the imprecision of the models used (see Flanagan 2003, p. 185), we elect to largely confine our discussion of corporatist notions to the consideration of social pacts or alliances involving the bargaining parties/social partners and the government (see Section 4). However, mention should be made here of the institutionalized corporatist model of Teulings and Hartog (1998) because of its contract-theoretic roots and incorporation of flexibility. As noted earlier, the mechanism through which corporatism achieves allocative efficiency in this framework is via the setting of ex ante binding contracts that obviate the need for inefficient ex post recontracting (once surpluses have been created). Rigid nominal contracts are therefore given a positive efficiency role. The basic model builds upon monopsonistic wage setting and a hold-up model of investments. In this setting, wage differentials stem from surpluses and these rents are said to be smaller in corporatist economies, the maintained hypothesis being that rent sharing is likely even in the absence of unions. Corporatism reduces the variance in wages that result from different processes and union policies. Given an aggregate demand shock, as opposed to shocks that are particular to each firm and "absorbed," nominal wage contracts are not adjusted locally. Rather, the corporatist institutions coordinate adjustments to these shocks. Corporatist coordination is said to be superior to mechanical adjustment rules because the latter cannot take all contingencies into account. In testing the model, wage differentials are taken as the key indicator of the efficiency of labor market processes, with corporatist economies displaying smaller noncompetitive differentials than their more market-oriented counterparts. Unfortunately, in addition to eschewing consideration of wages/changes in wages, the model does not directly tackle unemployment either. Explanation of the latter is simply laid at the door of the social security system. Nonetheless, an enduring contribution of this model is the notion that institutional structures have an historical and social context, their interdependence once again suggesting that what works in one economy may not work in another.

${ }^{7}$ But see Ochel (2005, pp. 105-106).

${ }^{8}$ The sources of oversimplification are twofold. First, we have neglected research investigating potential interactions between labor market policies and the institutional features of the collective bargaining system (on the effects of which, see inter al. OECD 2004; Elmeskov et al. 1998; Belot and van Ours 2004). Second, we have ignored work on interactions between collective bargaining and monetary and fiscal policy, such as that between coordinated wage bargaining and central bank independence (for a compact survey of which, see Aidt and Tzannatos 2008, pp. 286-290).

${ }^{9}$ Using data from the ICTWSS Database on 25 European countries (adding Slovenia, Slovakia, Estonia, Latvia, Lithuania, the Czech Republic, Hungary, and Poland to the countries shown in Table 2) for the years 2000-2009, Visser (2013, p. 16) obtains a simple correlation coefficient of $r=0.80$ between the level of employer organization (ranked as strong/medium/weak) and the bargaining coverage rate. The corresponding correlation coefficient between coverage and union density is $r=0.50$. See also Visser 
(2016, pp. 9-11). His broader conclusion, however, is that coverage rates and employer organization move together rather than the latter causing the former. Thus, for example, both may be determined by extension procedures.

${ }^{10}$ Visser (2016, Table 1) provides indicative estimates of the effect of extension agreements in terms of the percentage of employees in employment affected.

${ }^{11}$ Decentralization has also been shaped by the state. The best known cases of state intervention are those in Greece, Portugal, Italy, and Spain during the Great Recession. Much earlier, the locus of bargaining shifted from the industry level to the enterprise level in France, beginning in 1982/1983 when a duty to bargain (over changes in hours) first became obligatory and at the same time direct employee representation was established at the workplace level. Thence, successive governments are described by Visser (2016, p. 19) as having "promoted the enterprise as a conduit for public policy exceptions, further enhancing the autonomy of the enterprise from the wider industrial relations system, together with a relocation of employee representation from the trade union to the non-union, firm-specific institutions in all but the largest firms."

${ }^{12}$ In a not dissimilar fashion, pattern bargaining may be supported by other institutions, such as conflict resolution procedures in Norway and Denmark where it is possible to end disputes over the renewal of agreements by means of a single mediation procedure for the entire sector, the mediator being empowered to treat several settlements as a single entity in the ballot. As Visser (2013, p. 61) notes, mediation can serve as a strong centralizing force in an otherwise decentralized system (viz. Denmark) or to contain "unruly" unions/employers (Norway).

${ }^{13} \mathrm{Namely}$, the elasticity of total revenue with respect to changes in employment, the productivity of insiders relative to outsiders, the weight of outsiders relative to insiders in union utility, the weight of wages relative to employment in union utility, and the real alternative income level

${ }^{14}$ That is, they recognize that other considerations may affect the relative outcomes of the two bargaining modes even if they are deemed rather "fussy" to be approached quantitatively.

${ }^{15}$ Drawing on data from the Wage Dynamics Network (see Section 2), Boeri provides five pieces of evidence in support of his critique. First, he reports that there does not seem to be any strong bias in favor of insiders at the plant level as compared with two-tier bargaining. Second, labor costs as a share of total costs are significantly higher in companies practicing two-tier bargaining. Third, two-tier structures provide significantly less performance-related pay than other bargaining forms and especially plantlevel bargaining. Fourth, the labor costs of countries with two-tier structures (identified as Austria, France, Greece, Ireland, Italy, and Portugal) have failed to deliver moderation in unit labor cost development vis-à-vis Germany, 2000-2013. Finally, he contends that there is little evidence on adjustment mechanisms to suggest that twotier bargaining can better cope with aggregate shocks. Boeri therefore concludes that two-tier structures do not allow for micro flexibility in wage setting, employment, and hours adjustment that decentralization under two-tier bargaining was supposed to achieve. The problem is that in his consideration of regimes, Boeri again risks putting too much into one basket.

${ }^{16}$ In his discussion of pattern bargaining in Austria, Traxler (1998) earlier identified the metal engineering group in the exposed sector as setting the pattern and internalizing 
the externalities by setting rates below the metalworking industry's own productivity increase. But Visser (2016, p. 27) questions whether this will continue in the future following the decision in 2012 of the employers making up the six constituent parts of that sector going their own way and signing separate agreements, comparable with the situation in Sweden after 1983 and until the late 1990s when pattern bargaining was contested.

${ }^{17}$ That said, the authors contend that decentralization has the more deleterious short-term effects.

${ }^{18}$ Today, the main union confederations provide annual recommendations on maximum wage increases that are a function of past developments in inflation and productivity and that are not exceeded in practice. As a practical matter, wage agreements that have historically set norms for minimum and maximum rates of pay are increasingly giving way to those that set minimum rates of pay.

${ }^{19}$ The interesting instruments include the 5-year cross-country unemployment rate interacted with a Ghent dummy (taking the value of 1 where unemployment benefits are managed by unions, 0 otherwise). Ghent refers to the provision or administration of unemployment insurance (UI) by trade unions. The Ghent system takes the form of either voluntary UI funds set up by unions that are subsidized by the state (in Finland, Denmark, and Sweden) or as a compulsory UI scheme partly administered by unions (Belgium). As can be seen from Table 2, these countries respectively enjoy the three highest and fifth-highest union densities, and this association is confirmed in cet. par. analyses (e.g., Ebbinghaus and Visser 1999).

${ }^{20} \mathrm{On}$ a legal reform agenda specific to the USA involving conditional deregulation and changes in the labor law default, see Hirsch (2004b).

\section{Acknowledgements}

The original version of this paper was prepared for the International Monetary Fund as background to an IMF-ITUC Workshop on Collective Bargaining, held at the IMF Headquarters in Washington, DC, on December 14, 2015. As in the original, all views expressed in this article are those of the author and do not necessarily reflect those of the IMF or its member countries. The author is much indebted to the Editor of this Journal, Juan F. Jimeno, and a particularly knowledgeable reviewer for the most constructive comments.

Responsible editor: Juan Jimeno

\section{Competing interests}

The IZA Journal of Labor Policy is committed to the IZA Guiding Principles of Research Integrity. The author declares that he has observed these principles.

Received: 1 April 2016 Accepted: 8 September 2016

Published online: 27 October 2016

\section{References}

Addison JT (2009) The Economics of Codetermination: Lessons from the German Experience. Palgrave Macmillan, New York

Addison JT, Belfield CR (2004a) Unions and Establishment Performance: Evidence from the British Workplace Industrial/ Employee Relations Surveys. In: Wunnava PV (ed) The Changing Role of Unions - New Forms of Representation. M.E. Sharpe, Armonk, pp 281-319

Addison JT, Belfield CR (2004b) Unions and employment growth: the one constant? Ind Relat 43(2):305-323

Addison JT, Hirsch BT (1989) Union effects on productivity, profits, and growth: has the long run arrived? J Labor Econ $7(1): 72-105$

Addison JT, Siebert WS (2003) Changes in Collective Bargaining in the U.K. In: Addison JT, Schnabel C (eds) International Handbook of Trade Unions. Elgar, Cheltenham and Northampton, pp 415-460

Addison JT, Teixeira P (2009) Are good industrial relations good for the economy? Ger Econ Rev 10(2):253-269

Addison JT, Bailey R, Siebert WS (2007) The impact of de-unionization on earnings dispersion revisited. Res Labor Econ 26:337-363

Addison JT, Teixeira P, Evers K, Bellman L (2013) Collective Bargaining and Innovation in Germany: Cooperative Industrial Relations? In: IZA Discussion Paper No. 7871. Institute for the Study of Labor, Bonn (forthcoming in Industrial Relations, January 2017) 
Addison JT, Teixeira P, Evers K, Bellman L (2015) Pacts for Employment and Competitiveness as a Role Model? Their Effects on Firm Performance. In: IZA Discussion Paper No. 9323. Institute for the Study of Labor/IZA, Bonn (forthcoming in British Journal of Industrial Relations)

Addison JT, Teixeira P, Evers K, Bellman L (2016a) Is the erosion thesis overblown? The process of alignment from without in Germany. Ind Relat 55(3):415-443

Addison JT, Portugal P, Vilares H (2016b) Unions and collective bargaining in the wake of the Great Recession: evidence from Portugal. Br J Ind Relat. doi:10.1111/bjir.12198

Aghion P, Algan Y, Cahuc P (2009) Civil society and the state: the interplay between cooperation and minimum wage regulation.". J Eur Econ Assoc 9(1):3-42

Aidt TS, Tzannatos Z (2002) Unions and Collective Bargaining: Economic Effects in a Global Environment. World Bank, Washington, DC

Aidt TS, Tzannatos Z (2008) Trade unions, collective bargaining and macroeconomic performance: a review. Ind Relat J 39(4):258-295

Algan Y, Cahuc P (2009) Civic virtue and labor market institutions. Am Econ J Macroecon 1(1):111-145

Avdagic S, Rhodes M, Visser J (2011) Social Pacts in Europe: Emergence, Evolution, and Institutionalization. Oxford University Press, Oxford

Babec y J, Du Caju P, Kosma T, Lawless M, Messina J, Rõõm T (2012) How do European firms adjust their labour costs when nominal wages are rigid? Labour Econ 19:792-801

Bassanini A (2011) Aggregate Earnings and Macroeconomic Shocks - The Role of Labour Market Policies and Institutions. In: OECD Social, Employment and Migration Working Papers No. 123. Organisation for Economic Co-operation and Development, Paris

Batt R, Welbourne TM (2002) Performance Growth in Entrepreneurial Firms: Revisiting the Union-Performance Relationship. In: Katz JA, Welbourne TM (eds) Research Volume in Entrepreneurship, vol 5. JAI Press, Oxford, pp 147-174

Belot M, van Ours JC (2004) Does the recent success of some OECD countries in lowering their unemployment rates lie in the clever design of their labour market reform? Oxf Econ Pap 56(4):621-642

Berg A, Ostry J, Zettelmeyer J (2012) What makes growth sustained? J Dev Econ 98(2):149-166

Berthold N, Fehn R (1996) Evolution von Lohnverhandlungssystemen - Macht oder ökonomisches Gesetz? In: Zohlnhöfer W (ed) Die Tarifautonomie auf dem Prüfstand. Duncker \& Humblot, Berlin

Bertola G, Dabusinskas A, Hoeberichts M, Izquierdo M, Kwapil C, Montornès J, Radowski D (2012) Price, wage and employment response to shocks: evidence from the WDN Survey.". Labour Econ 19:783-791

Black S, Lynch LM (2001) How to compete: the impact of workplace practices and information technology on productivity. Rev Econ Stat 83(3):434-445

Blanchard O, Phillipon T (2004) The Quality of Labor Relations and Unemployment. In: NBER Working Paper No. 10590. National Bureau of Economic Research, Cambridge

Blanchard O, Phillipon T (2006) The Quality of Labor Relations and Unemployment. In: NYU Working Paper No. FIN-06-038. Stern School of Business, New York University, New York

Blanchard O, Wolfers J (2000) The role of shocks and institutions in the rise of European unemployment. Econ J 110(462):C1-C33

Blanchard O, Jaumotte F, Loungani P (2013) Labor Market Policies and IMF Advice in Advanced Economies during the Great Recession. In: IMF Staff Discussion Note SDN/13/02. International Monetary Fund, Washington, DC

Blanchflower DG, Bryson A (2003) Changes over Time in Union Relative Wage Effects in the U.K. and the U.S. Revisited. In: Addison JT, Schnabel C (eds) International Handbook of Trade Unions. Edward Elgar, Cheltenham and Northampton, pp 118-171

Boeri T (2014) Two-Tier Bargaining. In: IZA Discussion Paper No. 8358. Institute for the Study of Labor/IZA, Bonn

Boeri T (2015) Perverse Effects of Two-Tier Wage Bargaining Structures. IZA World of Labor, Institute for the Study of Labor/IZA, Bonn, Available at: http://wol.iza.org/articles/perverse-effects-of-two-tier-wage-bargaining-structures-1.pdf

Boeri T, Burda MC (2009) Preferences for collective versus individualised bargaining. Econ J 119(540):1440-1463

Bowdler C, Nunziata L (2007) Trade union density and inflation performance: evidence from OECD panel data. Economica 74(293):135-159

Brändle T, Goerke L (2015) The One Constant: A Causal Effect of Collective Bargaining on Employment Growth? Evidence from German Linked-Employer-Employee Data. In: IAAEU Discussion Paper Series in Economics No. 01/2015. Institute for Labour Law and Industrial Relations in the European Union, Trier

Brändle T, Heinbach WD (2013) Opening clauses in collective bargaining agreements: more flexibility to save jobs? Rev Econ/Jahrbuch für Wirtschaftswissenschaften 64(2):159-192

Bryson A (2010) Union Effects on Wages. In: David Marsden D, Rycx F (eds) Wage Structures, Employment Adjustments, and Globalization: Evidence from Linked and Firm-Level Panel Data. Palgrave Macmillan, Basingstoke, pp 174-184

Bryson A, Forth J, Laroche P (2011) Evolution or revolution? The impact of unions on workplace performance in Britain and France. Eur J Industrial Relat 17(2):71-87

Bryson A, Willman P, Gomez R, Kretschmer T (2013) The comparative advantage of non-union voice in Britain, 1980-2004. Ind Relat 52(S1):194-220

Calmfors L, Driffill J (1988) Bargaining structure, corporatism, and macroeconomic performance. Econ Policy 3(6):13-62

Card D, Lemieux T, Riddell WC (2003) Unions and Wage Inequality. In: Addison JT, Schnabel C (eds) International Handbook of Trade Unions. Edward Elgar, Cheltenham and Northampton, pp 114-159

Card D, Lemieux T, Riddell WC (2004) Unions and wage inequality. J Lab Res 25(4):519-562

Card D, Heining J, Kline P (2013) Workplace heterogeneity and the rise of German wage inequality. Q J Econ 128(3):967-1015

Dabla-Norris E, Kochhar K, Suphaphiphat N, Ricka F, Tsounta E (2015) Causes and Consequences of Income Inequality: A Global Perspective. In: IMF Discussion Note SDN/15/13. International Monetary Fund, Washington, DC

Den Butter FAG, Mosch RHJ (2003) The Dutch miracle: institutions, networks, and trust. J Inst Theor Econ/Zeitschrift für die gesamte Staatswissenschaft 159(2):362-391

Díez-Catalán L, Villanueva E (2014) Contract Staggering and Unemployment During the Great Recession: Evidence from Spain. Documentos de Trabajo N. ${ }^{\circ}$ 1431. Banco de España, Madrid 
DiNardo J, Lee DS (2004) Economic impacts of new unionization on private sector employers, 1984-2001. Q J Econ 119(4):1383-1442

DiNardo J, Fortin N, Lemieux T (1996) Labor market institutions and the distribution of wages, 1973-1992: a semiparametric approach. Econometrica 64(5):1001-1044

Doucouliagos H, Laroche P (2003) What do unions do to productivity? A meta-analysis. Ind Relat 42(4):650-691

Doucouliagos H, Laroche P (2009) Unions and profits: a meta-regression analysis. Ind Relat 48(1):146-184

Druant M, Fabiani S, Kezdi G, Lamo A, Martins F, Sabbatini R (2012) Firms' price and wage adjustment in Europe: survey evidence on nominal stickiness. Labour Econ 19:772-782

Dunne T, Macpherson DA (1994) Unionism and gross employment flows. South Econ J 60(3):727-738

Dustmann C, Ludsteck J, Schönberg U (2009) Revisiting the German wage structure. Q J Econ 124(2):843-881

Dustmann C, Fitzenberger B, Schönberg U, Spitz-Oener A (2014) From sick man of Europe to superstar: Germany's resurgent economy. J Econ Perspect 28(1):167-188

Ebbinghaus B, Visser J (1999) When institutions matter - union growth and decline in Western Europe. Eur Sociol Rev 15(2):135-158

Ellguth P, Gerner H-D, Stegmaier J (2014) Wage effects of works councils and opening clauses: the German case. Econ Ind Democr 35(1):95-113

Elmeskov J, Martin JP, Scarpetta S (1998) Key lessons for labour market reforms: evidence from OECD countries' experiences. Swedish Econ Pol Rev 5(2):205-252

Fairris D, Askenazy P (2010) Works councils and firm productivity in France. J Lab Res 31(3):209-229

Fitzenberger B, Franz W (1999a) Der Flächentarifvertrag: Eine kritische Würdigung aus ökonomischer Sicht. In: Franz W, Ramser HJ, Stadler M (eds) Ökonomische Analyse von Verträgen. Mohr Siebeck, Tübingen, pp 3-41

Fitzenberger B, Franz W (1999b) Industry-level wage bargaining: a partial rehabilitation - the German experience. Scottish J Political Econ 46(34):437-457

Fitzenberger B, Kohn K, Lembcke AC (2013) Union density and varieties of coverage: the anatomy of union wage effects in Germany. Ind Labor Relat Rev 66(10):169-197

Flanagan RJ (2003) Collective Bargaining and Macroeconomic Performance. In: Addison JT, Schnabel C (eds) International Handbook of Trade Unions. Edward Elgar, Cheltenham and Northampton, pp 172-196

Flanagan RJ, Hartog J, Theeuwes J (1993) Institutions and the Labour Market: Many Questions, Some Answers. In: Hartog J, Theeuwes J (eds) Labour Market Contracts and Institutions. A Cross-National Comparison, North- Holland, Amsterdam, pp 415-456

Freeman RB (1976) Individual mobility and union voice in the labor market. Am Econ Rev Pap Proc 66(2):361-368

Freeman RB (1993) How Much Has Deunionization Contributed to the Rise of Male Earnings Inequality? In: Danziger S, Gottschalk P (eds) Uneven Tides: Rising Inequality in America. Russell Sage Foundation, New York, pp 133-163

Freeman RB (1998) War of the models: which labour market institutions for the 21st century? Labour Econ 5:1-24

Freeman RB, Lazear EP (1995) An Economic Analysis of Works Councils. In: Rogers J, Streeck W (eds) Consultation, Representation and Cooperation in Industrial Relations. University of Chicago Press, Chicago, pp 27-52

Freeman RB, Medoff JL (1984) What Do Unions Do? Basic Books, New York

Freeman RB, Pelletier J (1990) The impact of industrial relations legislation on British union density. Br J Ind Relat 29(2):141-164

Galuscak K, Keeney M, Nicolitsas D, Smets F, Strzelecki P, Vodopivec M (2012) The determination of wages of newly hired employees: survey evidence on internal versus external factors. Labour Econ 19:802-812

Garloff A, Guertzgen N (2012) Collective wage contracts, opt-out clauses, and firm wage differentials: evidence from linked employer-employee data. Ind Relat 51(3):731-748

German Council of Economic Experts (1996) Pushing Forward with Reforms. Annual Report 1996/97 (Sachverständigenrat zur Begutachtung der gesamtwirtschaftlichen Entwicklung). Metzler-Poeschel, Stuttgart

Hassel A (2003) The politics of social pacts. Br J Ind Relat 41(4):707-726

Hirsch BT (1991) Labor Unions and the Economic Performance of U.S. Firms. Upjohn Institute for Employment Research, Kalamazoo

Hirsch BT (2004a) Reconsidering union wage effects: surveying new evidence on an old topic. J Lab Res 25(2):233-266

Hirsch BT (2004b) What do unions do for economic performance? J Lab Res 25(3):415-455

Hübler O, Jirjahn U (2003) Works councils and collective bargaining in Germany: the impact on productivity and wages. Scottish J Political Econ 50(4):471-491

Jansen G (2014) Effects of union organization on strike incidence in EU companies. Ind Labor Relat Rev 67(1):60-85

Jaumotte F, Osorio-Buitron C (2015) Inequality and Labor Market Institutions. 2015. In: IMF Discussion Note SDN/15/14. International Monetary Fund, Washington, DC

Jimeno JF, Thomas C (2013) Collective bargaining, firm heterogeneity and unemployment. Eur Econ Rev 59:63-79

Katz HC, Kochan TA, Gobeille KE (1983) Industrial relations performance, economic performance, and QWL programs: an interplant analysis. Ind Labor Relat Rev 37(1):3-17

Kleiner MM, Leonard JS, Pilarski AM (2002) How industrial relations affect plant performance: the case of commercial aircraft manufacturing. Ind Labor Relat Rev 55(2):195-218

Krueger AB, Mas A (2004) Strikes, scabs and tread separations: labor strife and the production of defective Bridgestone/ Firestone tires. J Polit Econ 112(2):253-289

Leonard JS (1992) Unions and Employment Growth. In: Bognanno MF, Kleiner MM (eds) Labor Market Institutions and the Future Role of Unions. Blackwell Publishers, Cambridge, pp 80-94

Marsden D (2015) The future of the German industrial relations model. J Labour Market Res 48(2):169-187

Martins PS (2014) 30,000 Minimum Wages: The Economic Effects of Collective Bargaining Extensions. In: IZA Discussion Paper No. 8540. Institute for the Study of Labor/IZA, Bonn

Menezes-Filho N, van Reenen J (2003) Unions and Innovation: A Survey of the Theory and Empirical Evidence. In: Addison JT, Schnabel C (eds) International Handbook of Trade Unions. Edward Elgar, Cheltenham and Northampton, pp 293-334

Metcalf D (2003) Unions and Productivity, Financial Performance and Investment: International Evidence. In: International Handbook of Trade Unions. Edward Elgar, Cheltenham and Northampton, pp 118-171 
Murtin F, de Serres A, Hijzen A (2014) Unemployment and the coverage extension of collective wage agreements. Labor Econ 71:52-66

Nickell SJ (1997) Unemployment and labor market rigidities: Europe versus North America. J Econ Perspect 11(3):55-74 Nickell SJ, Nunziata L, Ochel W (2005) Unemployment in the OECD since the 1960s. What do we know? Econ J 115(500):1-33

Nienhueser W, Hossfeld H (2011) The effects of trust on the preference for decentralized bargaining: an empirical study of managers and works councillors. SAGE Open. doi:10.1177/2158244011425691

Ochel W (2005) Decentralizing wage bargaining in Germany - a way to increase employment? Labour 19(1):91-121

OECD (1994) The OECD Jobs Study, Evidence and Explanation, Part II: The Adjustment Potential of the Labour Market. Organisation for Economic Co-operation and Development, Paris

OECD (1997) Economic Performance and the Structure of Collective Bargaining. Employment Outlook 1997:63-92

OECD (2004) Wage Setting Institutions and Outcomes. Employment Outlook 2004:127-181

OECD (2006) Reassessing the Role of Policies and Institutions for Labour Market Performance: A Quantitative Analysis. Employment Outlook 2006:207-231

OECD (2010) Institutional and Policy Determinants of Labor Market Flows. Employment Outlook 2010:167-210

OECD (2012) OECD Economic Surveys: Portugal 2012. Organisation for Economic Co-operation and Development, Paris OECD (2014) Rising Inequality: Youth and Poor Fall Further Behind. Insights from the OECD Income Distribution Database. Income Inequality Update. Organisation for Economic Co-operation and Development, Paris, Available at: https://www.oecd.org/social/OECD2014-Income-Inequality-Update.pdf

Pencavel JH (2005) Unionism viewed internationally. J Lab Res 26(1):66-97

Pontusson J (2013) Unionization, inequality, and redistribution. Br J Ind Relat 51(4):797-825

Schnabel C (2013) Union membership and density: some (not so) stylized facts and challenges. Eur J Industrial Relat 19(3):255-272

Sojourner A, Town RJ, Grabowski DC, Chen MM (2012) Impacts of Unionization on Employment, Product Quality, and Productivity: Regression Discontinuity Evidence from Nursing Homes. In: NBER Working Paper No. 17733. National Bureau of Economic Research, Cambridge

Teague P, Grahl J (1998) Institutions and labour market performance in Western Europe. Political Stud 46(1):1-18

Teulings C, Hartog J (1998) Corporatism or Competition? Labour Contracts, Institutions, and Wage Structures in International Competition. Cambridge University Press, Cambridge

Traxler F (1998) Austria: Still the Country of Corporatism? In: Ferner A, Hyman R (eds) Changing Industrial Relations in Europe. Blackwell, Oxford, pp 239-261

Traxler F, Brandl B (2009) The Effects of Collective Bargaining Coverage: A Cross-National Analysis. In: Global Union Research Network Discussion Paper No. 110. International Labour Office, Geneva

Traxler F, Brandl B (2012) Collective bargaining, inter-sectoral heterogeneity and competitiveness: a cross-national comparison of macroeconomic performance. Br J Ind Relat 50(1):73-98

Traxler F, Blaschke S, Kittel B (2001) National Labor Relations in Internationalized Markets. Oxford University Press, Oxford

Van den Berg A, Grift Y, van Witteloostuijn A, Boone C, van der Brempt O (2013) The Effect of Employee Workplace Representation on Firm Performance. A Cross-country Comparison within Europe. In: Discussion Paper Series No. 13-05. Tjalling C. Koopmans Research Institute, Utrecht School of Economics, University of Utrecht, Utrecht

Villanueva E (2015) Employment and Wage Effects of Extending Collective Bargaining Agreements. IZA World of Labor. Institute for the Study of Labor/IZA, Bonn, Available at: http://woliza.org/articles/employment-and-wage-effects-ofextending-collective-bargaining-agreements-1.pdf

Visser J (2013) Wage bargaining institutions - from crisis to crisis. In: European Economy, Economic Papers 488. European Commission Directorate-General for Financial Affairs, Brusssels

Visser J (2016) What happened to collective bargaining during the great recession? J Labor Market Pol 5(9):1-35. doi:10. 1186/s40173-016-0061-1

Wood S, de Menezes L (1998) High commitment management in the U.K.: evidence from the Workplace Industrial Relations Survey and the Employers' Manpower and Skills Practices Survey. Human Relations 51(4):485-515

\section{Submit your manuscript to a SpringerOpen ${ }^{\circ}$ journal and benefit from:}

- Convenient online submission

- Rigorous peer review

- Immediate publication on acceptance

- Open access: articles freely available online

- High visibility within the field

Retaining the copyright to your article 